\title{
School-based sexual health education interventions to prevent STI/HIV in sub- Saharan Africa: a systematic review and meta-analysis
}

\author{
A. Sadiq Sani ${ }^{1 *}$, Charles Abraham¹, Sarah Denford ${ }^{1}$ and Susan Ball ${ }^{2}$
}

\begin{abstract}
Background: School-based sexual health education has the potential to provide an inclusive and comprehensive approach to promoting sexual health among young people. We reviewed evaluations of school-based sexual health education interventions in sub-Saharan Africa to assess effectiveness in reducing sexually transmitted infections and promoting condom use.

Methods: We searched ten electronic databases, hand-searched key journals, and reference lists of included articles for potential studies. Data were extracted on outcomes, intervention characteristics, methods and study characteristics indicative of methodological quality. Where possible, data were synthesized using random effect meta-analysis. Intervention features found predominantly in effective interventions were noted.

Results: The initial search retrieved 21634 potentially relevant citations. Of these, 51 papers reporting on 31 interventions were included. No evaluation reported statistically significant effects on the incidence or prevalence of Human Immunodeficiency Virus and Herpes Simplex Virus 2 infections. However, intervention participants reported statistically significant greater condom use in both randomised controlled trials and non-randomised trials for short (less than 6 months) follow-up periods ( $O R=1.62,95 \% \mathrm{Cl}=1.03-2.55$ and $O R=2.88,95 \% \mathrm{Cl}=1$. 41-5.90 respectively). For intermediate (6-10 months) and long-term (more than 10 months) follow-up periods, the effect was statistically significant $(O R=1.40,95 \% \mathrm{Cl}=1.16-1.68)$ and marginally significant $(O R=1.22,95 \% \mathrm{Cl}=0$. 99-1.50) among the randomised trials respectively. Only 12 of the 31 interventions reported implementation details, out of which seven reported on fidelity.
\end{abstract}

Conclusion: School-based sexual health education has the potential to promote condom use among young people in sub-Saharan Africa. However, further work is needed to develop and evaluate interventions that have measurable effects on sexually transmitted infections.

Keywords: Systematic review, School-based sexual health education, Sub-Saharan Africa, HIV/STI prevention

\footnotetext{
* Correspondence: A.Sadiq@exeter.ac.uk

${ }^{1}$ Psychology Applied To Health, University of Exeter Medical School, College

House, St Lukes Campus, Exeter EX1 2 LU, UK

Full list of author information is available at the end of the article
} 


\section{Background}

Worldwide, more than one million cases of sexually transmitted infections (STIs) occur daily and 500 million people live with curable STIs including Chlamydia, Gonorrhoea, Syphilis and Trichomoniasis [1]. The burden of STIs is high in sub-Saharan Africa (sSA) with an incidence rate of 241 per 1000 among adults age 15-49, one of the highest in the world [2]. Approximately $70 \%$ of those living with Human Immunodeficiency Virus (HIV) worldwide, and $80 \%$ of infected women aged 15-24, live in sSA where one in six adolescent deaths is attributed to HIV $[3,4]$. Approximately half of new HIV infections occur in individuals aged 15-24 [5] and more than $90 \%$ are sexually transmitted. Thus, sexually active young people in sSA, including young women, are at high risk of HIV infection.

Several types of interventions have been employed to reduce the vulnerability of adolescents to STIs, including HIV. These include: preventive education in schools; services delivered in youth centres, including condom distribution; adolescent-friendly health centres that encourage utilisation of prevention services; school-based health services; conditional cash transfers to encourage young people to remain in school or to avoid risky sexual behaviours; various community-based interventions; and unconditional cash transfers [6]. School-based sexual health education (SBSHE) is arguably the most inclusive and potentially comprehensive of these approaches and has the potential to effectively promote population-level sexual health among adolescents and young adults [7], so reducing the spread of STIs, including HIV [8]. Mavedzenge et al. [6] found high quality evidence for effectiveness of SBSHE in relation to a number of STI-related outcomes from evaluations worldwide and recommended such interventions be implemented widely. However, evaluations of SBSHE interventions in SSA have provided mixed findings in relation to reduction of self-reported unprotected sexual intercourse and surprisingly, none has provided evidence of reduction of STI incidence or prevalence [8-10]. In this review, SBSHE was defined as any intervention delivered wholly or partially in a school setting aiming to reduce risky sexual behaviours, STIs and unplanned pregnancy, and promote positive sexual health.

Four reviews of evaluations of SBSHE interventions in Africa were found [8-10]. None assessed effects of interventions on STI incidence or prevalence. A review by Kaaya et al. [9] included 11 interventions and concluded that most studies reported effects on knowledge, attitudes and communication but fewer reported effects on self-reported onset of sexual intercourse, frequency of sexual intercourse and number of sexual partners. Similarly, a review by Gallant and Maticka-Tyndale [8] also including 11 interventions and concluded that knowledge and attitudes are easier to change than behaviours among African youths. These reviewers recommended that intervention design should be grounded in theorized accounts of behaviour change mechanisms and be directly relevant to local culture. A third review by Paul-Ebhohimhen et al. [10], including 10 evaluations, also concluded that SBSHE interventions had stronger effects on sexual health knowledge and attitudes than on behaviour patterns. More optimistically, a review of seven interventions for Nigerian students found changes in self-reported sexual behaviour patterns including delaying sexual debut, increasing condom and other contraceptives use and reducing frequency of sexual activity [11]. Other reviews include SBSHE interventions [5, 12-26] but draw no conclusions about SBSHE in SSA.

\section{The present study}

This review extends previous reviews of effectiveness of SBSHE interventions in SSA [8-10] in four key respects. First, we include an updated and more comprehensive set of experimental evaluations. Second, we assess intervention effects on reduction of STIs indexed by biological markers. Third, we explore intervention characteristics that may differentiate between effective and ineffective interventions. Fourth, we examine assessment of implementation fidelity.

The review addressed three research questions:

1. How effective are school-based sexual health education interventions in sub-Saharan Africa in promoting condom use and preventing sexually transmitted infections?

2. What characterizes effective school-based sexual health education interventions implemented in sub-Saharan Africa?

3. Are school-based sexual health education interventions implemented with fidelity in sub-Saharan Africa?

\section{Methods}

This review was conducted according to a protocol [see Additional file 1, for the review protocol], and reported in accordance to PRISMA statement [27].

\section{Inclusion criteria}

Studies were included if they met the following criteria:

i. Published in English before March 2016.

ii. The study was a randomised control trial (RCT) or quasi-experimental (non-randomised trials and before-and-after studies with comparison groups).

iii. More than $80 \%$ of participants were below the age of 25 years. A 25 year cut-off was applied because age of school enrolment varies considerably across sub-Saharan Africa, particularly in the rural areas. Hence, it is not uncommon to find older students in primary or secondary schools [28]. 
iv. The study evaluated a school-based sexual health education intervention delivered in sub-Saharan African schools. The intervention could be delivered completely in school or include components delivered to school students outside school and/or outside school hours.

v. The dependent measure was self-reported condom use and/or levels of STIs.

\section{Exclusion criteria}

Studies were excluded for the following reasons:

i. They employed no comparison or control group.

ii. They employed a comparison group that received sexual health education other than the usual curriculum.

iii. They were delivered in universities.

iv. Twenty percent or more of the participants were aged 25 years and above.

v. Knowledge, attitudes and behavioural intentions were the only outcomes reported.

\section{Search strategy}

Ten electronic databases including Medline, PsycInfo, EMBASE, CINAHL, Web of Knowledge, The Cochrane Library, British Education Index/EBSCOhost, Australian Education Index/ProQuest, Education Research Complete/ EBSCOhost and ERIC/ProQuest were searched in February 2015 (see Additional file 2: Table S2, which contains search strategy for Medline that was modified and used in other databases). One new inclusion was identified in an updated search run in March 2016. We also searched the table of contents of Journal of AIDs, AIDs Care, AIDs and Behaviour, AIDs Education and Prevention, Journal of Adolescent Health, and Journal of Youth and Adolescence for relevant studies. Reference lists of similar reviews and included studies were also searched in an iterative fashion until no new article was found.

\section{Study selection}

Titles and abstracts of the 21,634 identified studies were screened by the primary reviewer (SAS) with a random selection $(n=500,2.3 \%)$ screened by a second reviewer (SD). Full texts of articles that passed the title-abstract stage were obtained for full text screening. All the full text articles were screened by SAS and $20 \%(n=53)$ randomly selected were screened independently by SD. Gwet's [29] AC1 statistic was used to assess the inter-rater reliability at each stage of the screening and any disagreement was resolved through discussion. The opinion of a third reviewer (CA) was sought when, exceptionally, two reviewers (SAS and $\mathrm{SD}$ ) were unsure how to resolve disagreements.

\section{Data extraction}

We extracted data relevant to the review questions, including study design, descriptions of the interventions, theories informing intervention design, features of effective interventions, descriptions of implementation and outcomes categorised by length of follow-up. The data extraction form is available as a Additional file 3: Table S3. Where more than one article described the same intervention, data were extracted from all papers. Data was extracted by the primary reviewer (SAS) and independently by a second reviewer (SD) to check accuracy. Furthermore, a statistician (SB) also extracted quantitative outcomes data included in meta-analysis independently.

\section{Quality assessment of included studies}

The quality of the included studies was assessed using four main dimensions based on recommendations in the Cochrane Collaboration Tool for Assessing Risk of Bias [30], namely selection bias, performance bias, detection bias, and attrition bias of the included studies. The Cochrane Collaboration Tool was used to assess the quality of included interventions because it is a domainbased evaluation that gives critical assessment of each domain (dimension) in which bias may arise [30]. It has the advantage of encouraging users to tailor how they assess studies and so adds to transparency unlike some other methodology assessment checklists (e.g., Jadad [31]). Selection bias for non-RCTs was assessed by determining selection bias due to confounding as recommended in the Cochrane Collaboration Handbook [30]. Random sequence generation or allocation concealment (or bias due to confounding for non-RCTs) and incomplete outcome data were considered critical for assessing the quality of studies in this review. The critical dimensions were used to score the overall risk of bias of the included studies. Random sequence generation and allocation concealment were scored as one dimension assessing selection bias. A score of two was given for 'high', one for 'unclear' and zero for 'low' risk of bias. Therefore, an intervention can have an overall score ranging from zero to four. An article with a total score of 3 or 4 was assessed as 'high', 2 as 'moderate' and 0 or 1 as 'low' risk of bias.

\section{Data analysis}

Review Manager 5.3 software [32] was used to undertake meta-analyses identifying intervention effectiveness in relation to increased condom use and reduced HSV2 infections using outcome measures closest to the median follow-up period. Separate analyses for condom use were conducted dividing evaluations into those with short (less than 6 months), intermediate (6-10 months, based on a median of 8 months) and long-term follow-up (more than 10 months). Random-effects method of meta-analysis that is based on inverse-variance technique that adjusts for 
varying study weights and heterogeneity was employed [30] because of variability in trial size and intervention content, intensity and duration. Whenever available, adjusted (for baseline) rather than crude odds ratios $(O R)$ were used in the analyses. Heterogeneity across estimates was quantified using the I-squared statistic $\left(I^{2}\right)$ and the $p$-value from the chi-squared test for heterogeneity was used to quantify evidence against homogeneity [30]. We did not include studies in meta-analysis if heterogeneity was high $\left(I^{2}\right.$ of $75 \%$ and above). Those studies that provided insufficient data to include in the meta-analyses were reported descriptively.

We also conducted sensitivity, or sub group, analyses to assess the effects of two study characteristics on effectiveness, namely, (i) the measure of condom use employed (condom use at last sex versus other measures) and (ii) use of crude versus adjusted odds ratios.

\section{Quality of evidence}

We used "Grading of Recommendations Assessment, Development and Evaluation" (GRADE) [33] to assess the overall quality of evidence reported in studies included in meta-analyses. This approach provides a structured and transparent way of developing and presenting results summaries that are easy to understand [33]. Five criteria were used in grading the evidence including limitations of design (risk of bias), inconsistency (heterogeneity), indirectness, imprecision, and reporting or publication bias. For limitations of design (risk of bias), the quality was downgraded if most of the studies were of high risk of bias as assessed with the Cochrane Collaboration Tool. For inconsistency, unexplained heterogeneity indicated by $I^{2}$ of more than $75 \%$ was used to downgrade the quality of evidence for this criterion. Indirectness was assessed by determining how closely the interventions, participants and measures of outcome of interest were similar across studies. A relative risk reduction or increase of greater than $25 \%( \pm 0.25)$ as suggested by GRADE was used to downgrade the quality of evidence for imprecision. Finally, visual inspection of asymmetry of funnel plots was used to detect the possibility of publication bias, and quality was downgraded if asymmetry was observed. These assessments were undertaken using GRADEpro software [34] and a summary of findings table (SoF) generated. The overall quality of each outcome was graded as 'high, 'moderate,' 'low' and 'very low'. These are interpreted as 'very confident,' 'moderately confident,' 'limited confidence' and 'very low confidence' that the true effect lies close to the estimated effect respectively [33].

\section{Features of effective interventions}

Intervention design and implementation characteristics associated with effectiveness have been identified in previous reviews. Design related features include: needs assessment with the intended participants and involving key stakeholders in the design or development process of the intervention $[5,10]$; adapting the intervention or curriculum from other evaluated interventions [5]; basing the intervention on behavioural change theory [9]; and providing the participants with skills that help reduce risky sexual behaviours [10). Implementation characteristics include: provision of adolescent-friendly health services [5]; distribution of condoms [5]; extending activities to the community outside the school environment [5]; training of facilitators; and fidelity of delivery [10]. Intervention descriptions in the current review were coded for inclusion of these features. We classified interventions as "interventions with evidence of benefit" or "interventions without evidence of benefit". "Evidence of benefit" was identified as a statistically significant increase condom use or less prevalence/incidence of STI at any follow-up among any sub-group of the participants (e.g., among sexually active participants). The frequency of occurrence of potentially effectiveness enhancing features among the interventions with evidence of benefit and those without evidence of benefit was then determined.

An intervention was regarded to have been delivered with fidelity if the authors reported that the intervention was delivered as intended. This includes how "faithful" components, content, and activities of the intervention were delivered as designed. It also includes frequency and duration of exposure (intensity) of the intervention.

\section{Results}

\section{Selection and description of studies}

We obtained 21,634 papers after removing duplicates (Fig. 1), out of which 271 were selected after screening through titles and abstracts $(\mathrm{AC} 1=0.98)$. After full-text screening two reviewers (SAS and SD) independently screened and agreed (100\% agreement, $\mathrm{AC} 1=1.0)$ on inclusion of 51 papers, reporting on 31 interventions. The Mema Kwa Vijana (MkV) intervention was reported in six included papers [35-40], however, Ross et al. [35] is cited henceforth when referring to this intervention because most data were extracted from that report. Similarly, other interventions reported in more than one paper include: (i) Primary School Action for Better Health (PSABH) $[41,42]$. (ii) HealthWise South Africa [43-46]. (iii) Promoting Sexual and Reproductive Health, School-based HIV/ AIDS Intervention in Sub-Saharan Africa (SATZ) [47-50]. (iv) HIV Prevention Intervention for Rural Youth (HP4RY) [51-54]. (v)'Let Us Protect Our Future' South Africa [55-57]. (vi) The Regai Dzive Shiri Project [58-61]. Subsequently, key papers $([41,43,47,51,55,58]$ respectively) are cited when referring to these interventions.

Seventeen of the evaluations were RCTs and 14 used quasi-experimental designs. Twenty-six of the interventions were delivered in secondary or high schools (84\%), four $(13 \%)$ in primary or elementary schools and SATZ intervention in both primary and secondary schools 


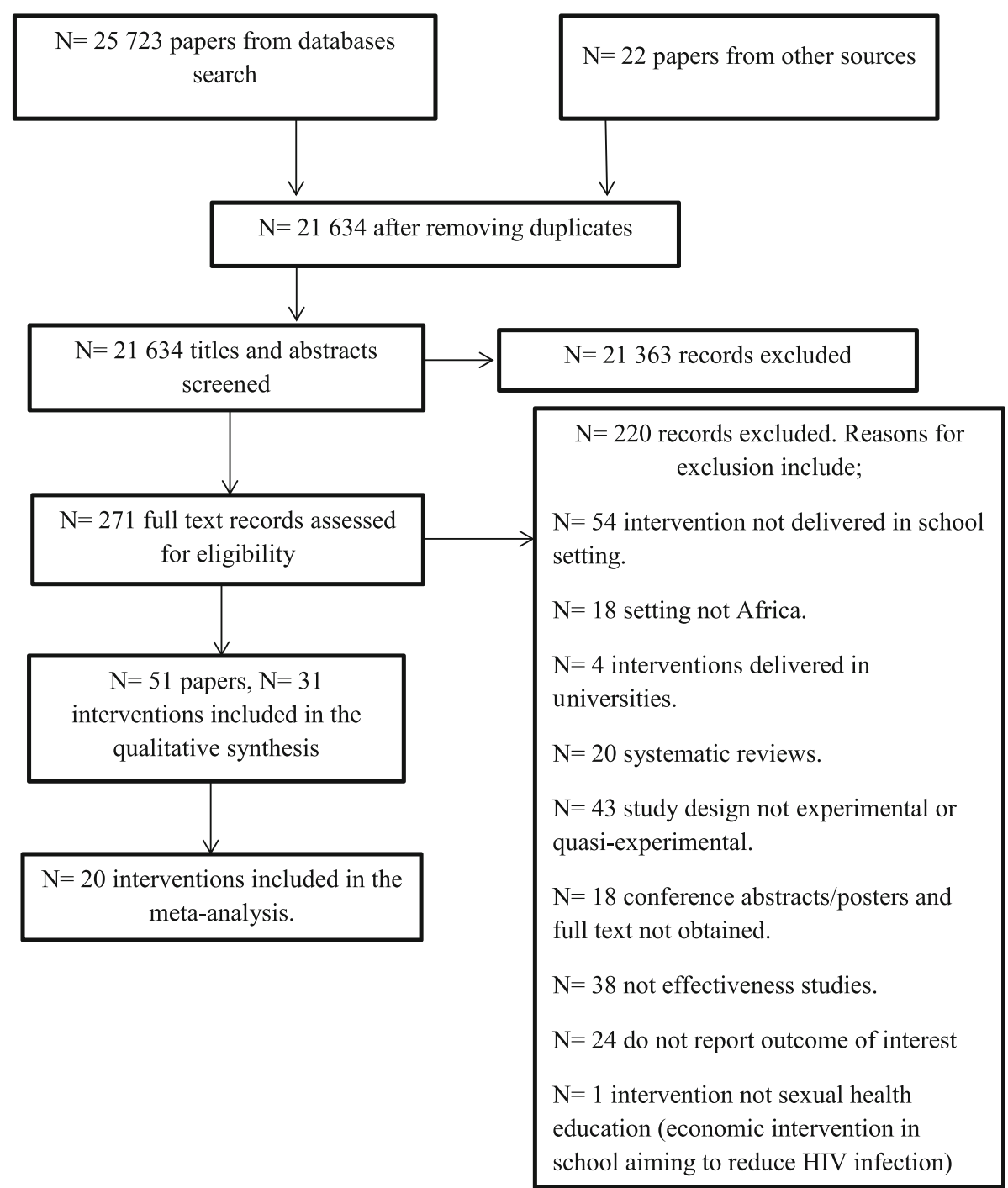

Fig. 1 Studies selection flow diagram

(3\%). Four interventions [35, 51, 58, 62] included out-ofschool and community activities, some involving health centres. The MkV intervention [35] had four components namely, a teacher- and peer-led in-school programme; provision of youth-friendly health services; condom promotion and distribution; and community mobilisation activities. The HP4RY intervention [51] had two components, a teacher delivered school programme and a community programme delivered by young people. The Regai Dzive Shiri Project [58], had three components, teacher-delivered school activities, community activities targeting parents and other community members, and provision of reproductive health services. The intervention by Brieger et al. [62] was a peer-led activity involving in-school activities as well as visits to, clinics and community centres activities. All interventions included in this review had both female and male participants, and participants were $9-30$ years old
$[55,63]$. The number of participants varied from 24 [64] to 13814 [35], with a total number 70201 across all included evaluations. The median follow-up period for condom use was 8 months and 54 months for the biological outcomes. See Additional file 4: Table S4, which provides lists of excluded studies with reasons for the exclusion and Table 1, which provides the characteristics of the included studies. Intervention descriptions included in Table 1 are summaries of those provided in the papers describing included interventions. All studies reported on ethical approval and/or received informed consent from the participants.

\section{Methodological quality of included studies}

Methodological quality was generally high; 20 of the included studies were assessed as having "low", 8 as "moderate" and 3 "high" risk of bias (see Additional file 5: Table S5, 
Table 1 Characteristics of Included Studies

\begin{tabular}{|c|c|c|c|c|c|c|}
\hline $\begin{array}{l}\text { STUDY } \\
\text { (lead author } \\
\text { surname and } \\
\text { date) }\end{array}$ & $\begin{array}{l}\text { SETTING (LEVEL } \\
\& \text { COUNTRY) }\end{array}$ & $\begin{array}{l}\text { STUDY } \\
\text { DESIGN }\end{array}$ & $\begin{array}{l}\text { PARTICIPANTS' } \\
\text { AGE (YEARS) \& } \\
\text { NUMBER }\end{array}$ & INTERVENTION & COMPARISON & $\begin{array}{l}\text { LENGTH (S) OF } \\
\text { FOLLOW UP }\end{array}$ \\
\hline $\begin{array}{l}\text { Aderibigbe } \\
2008\end{array}$ & $\begin{array}{l}\text { Secondary schools, } \\
\text { Nigeria }\end{array}$ & Quasi-experimental & $\begin{array}{l}\text { Age range: } 10-19 \\
\text { Number: } 521\end{array}$ & $\begin{array}{l}\text { Objectives: to reduce risky sexual behaviours. } \\
\text { Content: topics on HIV/AIDs, sexual behaviours } \\
\text { including condom use and risks of exchange } \\
\text { of sex for gifts were covered. } \\
\text { Activities: health education sessions consisting } \\
\text { of lectures, film shows, and distribution of } \\
\text { information, education and communication } \\
\text { (IEC) materials. } \\
\text { Dose/frequency/duration: not reported (NR) } \\
\text { Theory used: NR }\end{array}$ & No intervention & 3 months \\
\hline Agha 2004 & $\begin{array}{l}\text { Secondary schools, } \\
\text { Zambia }\end{array}$ & Quasi-experimental & $\begin{array}{l}\text { Age range: } 14-23 \\
\text { Number: } 416\end{array}$ & $\begin{array}{l}\text { Objectives: to increase knowledge, normative } \\
\text { belief and self-risk perception of contracting HIV. } \\
\text { Content: curriculum provided factual information } \\
\text { on HIV, modes of transmissions, impact of the } \\
\text { infection on immunity, high risk associated with } \\
\text { anal sex and other non-sexual modes of transmission } \\
\text { of HIV. It also contained information on abstinence, } \\
\text { correct and consistent use of condom. } \\
\text { Activities: peer led discussions, drama skits and } \\
\text { distribution of educational leaflets. } \\
\text { Dose/frequency/duration: one session of } \\
\text { 1-h-and-45-min duration. } \\
\text { Theory used: NR }\end{array}$ & $\begin{array}{l}\text { 1-h-long, peer-led water } \\
\text { purification intervention. }\end{array}$ & 1 week and 6 months \\
\hline Ajuwon 2007 & $\begin{array}{l}\text { Secondary schools, } \\
\text { Nigeria }\end{array}$ & Quasi-experimental & $\begin{array}{l}\text { Age range: } 10-25 \\
\text { Number: } 494\end{array}$ & $\begin{array}{l}\text { Objectives: to improve secondary school students' } \\
\text { sexual health knowledge, attitudes, perceived } \\
\text { self-efficacy and sexual practices. } \\
\text { Content: information on aspects of reproductive } \\
\text { health, STI/HIV/AIDS and condoms were covered. } \\
\text { Activities: teacher instructions, presentations, } \\
\text { rotational talks, health quiz competitions, drama } \\
\text { presentations, counselling of students and } \\
\text { distribution of condoms with other educational } \\
\text { materials. } \\
\text { Dose/frequency/duration: nine months (i.e., one } \\
\text { academic session) } \\
\text { Theory used: NR }\end{array}$ & No intervention & Immediate \\
\hline Arnold 2012 & $\begin{array}{l}\text { Secondary schools, } \\
\text { Nigeria }\end{array}$ & $\begin{array}{l}\text { Cluster Randomised } \\
\text { Controlled Trial }\end{array}$ & $\begin{array}{l}\text { Age range: greater } \\
\text { than } 11 \text { to less } \\
\text { than } 17 \\
\text { Number: } 2589\end{array}$ & $\begin{array}{l}\text { Objectives: to reduce vulnerability of youths to } \\
\text { HIV infection. } \\
\text { Content: the school curriculum included topics } \\
\text { on human development, HIV infection, sexual } \\
\text { behaviours, personal skills, relationships, and } \\
\text { society and culture. } \\
\text { Activities: the participants received family life } \\
\text { and HIV education programme in schools } \\
\text { as well as community interventions from }\end{array}$ & $\begin{array}{l}\text { No intervention while } \\
\text { waiting for delayed } \\
\text { intervention. }\end{array}$ & 12 months and 18 months \\
\hline
\end{tabular}


Table 1 Characteristics of Included Studies (Continued)

\begin{tabular}{|c|c|c|c|c|}
\hline & & & & $\begin{array}{l}\text { youths trained in working with youths } \\
\text { and adults. } \\
\text { Dose/frequency/duration: the school curriculum } \\
\text { was delivered over } 3 \text { years of junior secondary } \\
\text { schools. } \\
\text { Theory used: Social Ecology Theory, Social Scripting } \\
\text { Theory and AIDs Competent Community Model }\end{array}$ \\
\hline Atwood 2012 & $\begin{array}{l}\text { Elementary or middle } \\
\text { school, Liberia }\end{array}$ & $\begin{array}{l}\text { Randomised } \\
\text { Controlled Trial }\end{array}$ & $\begin{array}{l}\text { Mean age: } 16.3 \\
\text { Number: } 812\end{array}$ & $\begin{array}{l}\text { Objectives: to promote attitudes and skills for safer sex. } \\
\text { Content: an eight-module programme designed } \\
\text { to promote attitudes and skills for safer sex. These } \\
\text { include positive attitudes towards condom use, } \\
\text { skills to negotiate condom use, refuse sex and } \\
\text { use condoms effectively. } \\
\text { Activities: NR } \\
\text { Dose/frequency/duration: one module per week } \\
\text { over eight weeks. } \\
\text { Theory used: Social Cognitive Theory and Theory } \\
\text { of Reasoned Action. }\end{array}$ \\
\hline Brieger 2001 & $\begin{array}{l}\text { Secondary, post- } \\
\text { secondary and } \\
\text { out of school } \\
\text { youths, Nigeria } \\
\text { and Ghana }\end{array}$ & Quasi-experimental & $\begin{array}{l}\text { Age: Adults below } \\
25 \text { years of age } \\
\text { Number: } 1784\end{array}$ & $\begin{array}{l}\text { Objectives: to improve knowledge of reproductive } \\
\text { health, and promote safe sex behaviours with } \\
\text { contraceptive use among sexually active adolescent. } \\
\text { Content: information on sexuality and reproductive } \\
\text { health, safer sex behaviours and contraceptives } \\
\text { was provided. } \\
\text { Activities: peer counselling, youth involvement in } \\
\text { information education and communication } \\
\text { materials development, drama, and provision } \\
\text { of contraceptives. Other activities include TV, } \\
\text { radio, youth centre activities, nurse workshops, } \\
\text { clinic visits, youth centre and street campaigns. } \\
\text { Dose/frequency/duration: } 18 \text { months. } \\
\text { Theory used: NR }\end{array}$ \\
\hline Burnett 2011 & $\begin{array}{l}\text { High schools, } \\
\text { Swaziland }\end{array}$ & $\begin{array}{l}\text { Randomised } \\
\text { Controlled Trial }\end{array}$ & $\begin{array}{l}\text { Mean age: } 17.35 \\
\text { Number: } 177\end{array}$ & $\begin{array}{l}\text { Objectives: an American HIV education programme } \\
\text { adapted for Swaziland to improve HIV related } \\
\text { knowledge, attitudes and safe sexual behaviours } \\
\text { including HIV testing. } \\
\text { Content of curriculum: Topics including "understanding } \\
\text { my body", basics of HIV and STls, HV testing, prevention } \\
\text { and treatment of HIV, stigma and discrimination for } \\
\text { people living with HIV, relationships and assertive behaviours. } \\
\text { Activities: interactive techniques such as role play } \\
\text { and group discussions. } \\
\text { Dose/frequency/duration: one hour per week for } \\
13 \text { weeks. } \\
\text { Theory used: Self-efficacy Theory. }\end{array}$ \\
\hline
\end{tabular}

Cowan 2010 Secondary schools Cluster Randomised Age range: 18-22 Objectives: a community-based multi-component \& community clinics, Controlled Trial Number: 6791 HIV prevention intervention aiming to change Zimbabwe

General health curriculum intervention which includes information on how to

prevent malaria, Tuberculosis,

knowledge that do not have

behavioural theory underpinning

and preventive skills.

\section{No intervention}

18 months

No intervention

No intervention

48 months 
Table 1 Characteristics of Included Studies (Continued)

Content: Modified version of MkV curriculum

(see Ross 2007 below). Also included sessions on

self-awareness, communication, self-belief and

gender issues.

Activities: peer educators led intervention; parents

and community stakeholders programme to

improve health knowledge, communication

between parents and youths; and community

support for adolescent reproductive health and

provision of reproductive health services by

nurses and staff working in rurat clinics.

Dose/frequency/duration: NR

Theory used: Social Learning Theory and The

Stages of Change Model.

Cupp 2008 High schools, South Africa

Cluster Randomised Age range: 13-18 Controlled Trial Number: 1095

Denison 2012 High schools, Zambia

Quasi-experimental Age range: 11 to less than 19 Number: 2476
Objectives: to reduce risky behaviours concerning alcohol and sex.

Content: $40 \%$ focused on alcohol-related issues, while the other $60 \%$ on reducing risky sexual activity to avoid HIV, other STIs and unwanted pregnancy.

Activities: role-plays, teachers and peers led group discussions and audio vignettes.

Dose/frequency/duration: 30-40 min per unit

(15 units in total) over 8 weeks.

Theory used: Social Learning Theory, Theory of Planned Behaviour and Social Inoculation Theory.

Objectives: to increase knowledge, attitudes and protective behaviours related to HIV and

reproductive health

Content: curriculum addressed life skills and sexual behaviours including abstinence, being faithful

and condom use.

Activities: provision of library materials and

counselling from a youth resource centre; volunteer

peer educators coordinated extracurricular activities;

educational events to communities on specific topics;

and workshops to teachers on specific topics as a

way of capacity building.

Dose/frequency/duration: 40 min weekly over

7-9 months.

Theory used: NR

Objectives: to reduce risky sexual behaviours

and improve quality of sexual behaviours among

school going adolescents.

Content: topics on puberty, reproduction,

contraception, and negotiation in relationships,

including training in assertiveness skills were

covered.

Activities: active learning through small group

discussions and games; skills development through
Regular Life Orientation curriculum.

No intervention 
Table 1 Characteristics of Included Studies (Continued)

role-play; and information dissemination through

leaflets. Subjects on puberty, reproduction,

contraception and negotiation/assertiveness skills

were taught.

Dose/frequency/duration: one session per week

over eight weeks.

Theory used: NR

Fawole 1999 Secondary schools, Randomised Nigeria Controlled Tria

James 2005 Secondary schools South Africa

Randomised Controlled Trial

James 2006 Secondary schools, South Africa
Mean age: 17.6

Objectives: to improve knowledge, attitude and

(intervention group), sexual risk behaviours of secondary school students.

17.8 (control group). Content: the course targeted knowledge, attitudes

Number: $450 \quad$ and sexual behaviours in relations to STls including HIV.

Activities: film shows, lectures, stories, role-plays,

songs, essays and debates as well as demonstration

on how to use a condom.

Dose/frequency/duration: two hours per session,

one session per week over six weeks.

Theory used: NR

Age range: 15 to Objectives: to improve knowledge, attitudes,

communication and behavioural intentions

communication and behavioural intentions

concerning sexually transmitted infection.

Content: Laduma print provides the reader with
information on sexually transmitted infections

and clears any misconception on the issue. It

also provides information that will bring about

attitudinal change on the participants including

safe sex behaviours, self efficacy and adaptation

safe sex behaviours, self-eficacy and adaptation

skills for safe sex behaviour. Condom use for
prevention of STI is clearly explained in Laduma.

Activities: Laduma print was given to participants

to read.

Dose/duration/frequency: once and take averagely one hour to read the print.

Theory Used: NR

Objectives: to improve knowledge of HIV/AIDS and its prevention; safer sex practices and

intentions to practice safer sex; and positive

attitudes toward condom use and people living

with AIDS

Content: topics included information about HIV and AIDS, modes of transmission, the immune system, the progression of HIV to AIDS, and how to avoid HIV infection. Knowledge, attitude to condom use and people living with AIDS, gender norms, and perceptions about sexual behaviour were addressed.

Activities: programs were delivered through

combination of different methods including

didactic and interactive group work, teaching and role-play guided by a prescribed manual.
No intervention

6 months

No intervention

Students in the control group received odd lessons about aspects of HIV and

structured format and

in some cases celebrated

awareness days on the topic. 
Table 1 Characteristics of Included Studies (Continued)

Karnell 2006 Secondary schools, Quasi-experimental Median age: 16 South Africa Number: 66
Cluster Randomised Age range: 9-18 Controlled Trial Number: 1057

Mason-Jones High schools, 2011 South Africa
Dose/duration/frequency: one lesson per week over two school terms (20 weeks)

Theory used: NR

Objectives: to increase knowledge on HIV risk reduction, sexuality, sexual maturation, sex role and rape myth beliefs, and skills/self-efficacy to negotiate sex.

Content: topics covered included HIV/STD

risk-reduction knowledge; behavioural belief

that support abstinence and condom use; skills

and self-efficacy negotiating abstinence and

condom use and to use condoms; and sex-

specific modules that addressed sexuality,

sexual maturation, appropriate sex roles, and

rape myth belief.

Activities: games, role-playing, group discussions,

brainstorming and comic workbooks using series of storylines and characters.

Dose/frequency/duration: 12 one hour modules

(delivered 2 modules per day) over 6 days.

Theory used: Social Cognitive Theory and

Theory of Planned Behaviour.

Objectives: to give facts related to HIV and

alcohol; consequence and alternatives to

drinking alcohol and having unprotected sex:

and techniques to resist drinking and having sex.

Content: half of the curriculum focused on

alcohol related issues, while the remaining half

on HIV-related issues.

Activities: the intervention was delivered as

monologues role-play delivered by four fictional

teenage characters that served the basis for class

discussion and group assignments.

Dose/duration/frequency: 10 units, 30 min each

over 8 weeks.

Theory used: Social Learning, Social Inoculation and Cognitive Behaviour Theory.

Quasi-experimental Age range: 15-16 Objectives: to delay sexual debut and increase use of condoms.

content: The intervention consisted of a mixture of taught weekly classroom sessions by peer educators following a standard curriculum

covering issues on relationships, well-being and sexual health and confidence building.

Activities: It consists of weekly classroom taught

sessions by peer educators trained on issues

related to sexual health, confidence building

sexual health and wellbeing.

Dose/frequency/duration: NR

Theory used: NR
Health-promotion intervention 3 months, 6 months,

designed to increase fruit $\quad 12$ months, 42 months and

and vegetable consumption 54 months

and physical activity and

decrease cigarette smoking

and alcohol use.

Regular Life Orientation

curriculum.

5 months

Comparison schools

received their usual Life

Orientation programme.
18 months 
Table 1 Characteristics of Included Studies (Continued)

\begin{tabular}{|c|c|c|c|c|c|c|}
\hline $\begin{array}{l}\text { Mason-Jones } \\
2013\end{array}$ & $\begin{array}{l}\text { High schools, } \\
\text { South Africa }\end{array}$ & Quasi-experimental & $\begin{array}{l}\text { Age range: } 15-16 \\
\text { Number: } 728\end{array}$ & $\begin{array}{l}\text { Objectives: a high school peer educators training } \\
\text { programme to improve safe sexual behaviours } \\
\text { and related psychosocial outcomes of the peer } \\
\text { educators. } \\
\text { Content: training included information about } \\
\text { sexual and reproductive health including HIV/AIDS } \\
\text { and about community services available, learning } \\
\text { about leadership, presentation skills, life skills } \\
\text { lessons, communication skills, group work and } \\
\text { community development. It also included the } \\
\text { development of psychosocial skills believed to } \\
\text { be protective in reducing risky sexual behaviours } \\
\text { such as goal orientation, critical thinking, self-esteem } \\
\text { and decision-making. } \\
\text { Activities: the intervention includes training peers } \\
\text { that involves giving information on reproductive } \\
\text { health including HIV/AIDs, availability of reproductive } \\
\text { health services, life skills, presentation skills, } \\
\text { communication skills, group work and community } \\
\text { development. } \\
\text { Dose/frequency/duration: two training sessions } \\
\text { (1 h each per month), } 11 \text { training sessions } \\
\text { (over 3-day camp). } \\
\text { Theory used: NR }\end{array}$ & $\begin{array}{l}\text { Students from comparison } \\
\text { schools received no } \\
\text { extra training. }\end{array}$ & 18 months \\
\hline Mathews 2012 & $\begin{array}{l}\text { High schools, } \\
\text { South Africa and } \\
\text { Primary Schools, } \\
\text { Tanzania }\end{array}$ & $\begin{array}{l}\text { Cluster Randomised } \\
\text { Controlled Trial }\end{array}$ & $\begin{array}{l}\text { Age range: } 12-14 \\
\text { Number: } 12139\end{array}$ & $\begin{array}{l}\text { Objectives: to reduce young adolescent risky } \\
\text { sexual behaviours including delaying sexual } \\
\text { debut and promoting condom use. } \\
\text { Content: topics included self-image and values } \\
\text { clarification; personal, social and physical } \\
\text { development, sexuality and reproduction; HIV, } \\
\text { AIDS, STIs and substance use; condom use; } \\
\text { gender roles; skills for protection and safety; } \\
\text { intimate partner violence; contraception; sexual } \\
\text { decision-making and sexual risk behaviour; } \\
\text { sexual risk assessment; myths and misconceptions; } \\
\text { healthy lifestyle; and reproductive health rights. } \\
\text { Activities: teacher led presentations, small group } \\
\text { discussions, skills training, small group activities, } \\
\text { role-play, condom demonstrations, quiz, drama, } \\
\text { song composition and homework to involve parents. } \\
\text { Dose/frequency/duration: one school semester of } \\
\text { approximately } 5 \text { months duration and 15-20 } \\
\text { school hours. } \\
\text { Theory used: Attitude-Social Influence Efficacy } \\
\text { (ASE) model. }\end{array}$ & No intervention & 6 months and $12-15$ months \\
\hline $\begin{array}{l}\text { Maticka- } \\
\text { Tyndale } 2007\end{array}$ & $\begin{array}{l}\text { Primary schools, } \\
\text { Kenya }\end{array}$ & Quasi-experimental & $\begin{array}{l}\text { Age range: } 11-16 \\
\text { Number: } 3452\end{array}$ & $\begin{array}{l}\text { Objectives: to provide information on transmission } \\
\text { of HIV and skills building to withstand social, } \\
\text { cultural or interpersonal pressure to involve in } \\
\text { risky sexual behaviours as well as skills to reduce } \\
\text { stigma to people living or affected by HIV. }\end{array}$ & $\begin{array}{l}\text { Control schools received } \\
\text { the country's ministry } \\
\text { of education, science } \\
\text { and technology guidelines } \\
\text { for HIV/AIDS education, }\end{array}$ & 18 months and 30 months \\
\hline
\end{tabular}

communication skills, group work and community development.

South Africa and

Cluster Randomised Age range: 12-14

oung adolescent risky

Content: topics included self-image and values Clarification; personal, social and physical

intimate partner violence; contraception; sexual colay, condom demonstrations, quiz, drama, song composition and homework to involve parents. school hours.

heory used: Attitude-Social Influence Efficacy

$\begin{array}{llll}\text { Maticka- } & \text { Primary schools, } & \text { Quasi-experimental } & \text { Age range: 11-16 } \\ \text { Tyndale 2007 } & \text { Kenya } & \text { Number: 3452 }\end{array}$ stigma to people living or affected by HIV. 
Table 1 Characteristics of Included Studies (Continued)

Content: information on HIV transmission,

prevention and prossion

addressed strategies and skills building for
resisting the social, cultural and interpersonal

pressures to engage in sexual intercourse, sessions

to combat stigmatization of people living with

or affected by HIV and care of people with AIDS.

Activities: teachers and peer supporters delivered

classroom lessons, facilitate HIV and AIDS learning

using anonymous question boxes, information

corners, school health clubs and other school

activities (assemblies and literary performance).

Dose/frequency/duration: once per week over

usual school period.

Theory used: Social Learning Theory.

Mba 2007 Secondary schools, Randomised Age range: 10-20 Nigeria Controlled Trial Number: 360

Menna 2015 Secondary Schools, Quasi-experimental Age range: 15-18 Ethiopia

Michielsen

Non-randomised Controlled Trial

(for about $80 \%$

of the participants)

Number: 560

Objectives: to improve knowledge of reproductive

health and attitudes towards reproductive health

issues.

Content: information on STIs including HIV and

family planning were provided during a workshop.

Activities: a workshop on sexually transmitted

diseases, HIV/AIDs, and family planning.

Dose/frequency/duration: three hours.

Theory used: NR

Objectives: to prevent and control HIV/AIDs

epidemic by changing knowledge, attitudes and

practices of school youths in urban Ethiopia.

Content: topics related to the structure and

functions of human reproductive system,

HIV/AIDS, prevention methods of HIV and risky sexual behaviours.

Activities: peer educators were trained to educate peers on structure and function of reproductive

organs, HIV/AIDs, risky sexual behaviours and

methods of prevention of HIV.

Dose/frequency/duration: at least $40 \mathrm{~min}$, two sessions per week.

Theory used: NR

Objectives: to reduce risky sexual behaviours and

Mean age: 18.41 (intervention group) and 17.60 (control

group)

Number: 1950 promotes sexual/productive health through

anti-AIDs-clubs.

Content: training of peers consisted of provision of information on HIV/AIDS, sexually transmitted diseases, family planning and pregnancies, the role of the peer educator and teaching methods including message transmission and counselling. Activities: peer educators teach students through group and individual counselling, songs, drama and other interactive activities to adopt positive and responsible behaviours. but had no PSABH

trained teachers or Peer

supporters in the schools.

3 months

6 weeks

No intervention

No intervention

6 months, 12 months 
Table 1 Characteristics of Included Studies (Continued)

Dose/frequency/duration: NR

Theory used: Theory of Reasoned Action, Social

Learning Theory, Diffusion of Innovations Theory and Health Belief Model.
Okonofua
Secondary schools, Randomised Nigeria
Controlled Trial

$2003 \quad$ Nigeria $\quad$ Controlled Trial

Rijsdijk 2011 Secondary schools, Uganda

Quasi-experimental Mean age: 16.1 Number: 1986

Ross 2007

$\begin{array}{lll}\text { Primary school and } & \text { Community } & \text { Age range: } 14-\geq 18 \\ \text { Health Centres, } & \text { Randomised Trial } & \text { Number: } 13814\end{array}$

Health Centres,

Randomised Trial

Number:

Tanzania

Mean age: 17.4

Number: 1247
Objectives: an intervention to improve STI

treatment-seeking behaviour and reduce STI

and 18.2 (control prevalence among Nigerian youths.

Content: information on STls and treatment were

provided during health club activities.

Activities: (1) establishment of reproductive health

clubs in schools that organises campaigns during

which health professional provide factual information

on STI and treatment. Other activities include: (1)

distribution of IEC materials, organizing debates,

symposia, drama, essay writing, film show on STI

treatment and prevention; (2) training of peer

educators to provide counselling to peers as well as

distribute IEC material on STI and refer those who

have symptoms of STIs to health care providers; and

(3) training of health care providers (medical

practitioners, patent medicine dealers and Pharmacist)

with emphasis on treatment algorithms, condom

promotion and partner tracing with treatment.

Dose/frequency/duration: 11 months.

Theory used: NR making, self-identity, sexual development, role of

friends, teachers, and media), gender equity, sexual

and reproductive rights, sexuality issues, sexual

health problems and the life skills necessary to

know how to avoid or deal with them.

of six months.
Objectives: To build self-esteem, personal decision

social environment, gender equity, sexual/reproductive right and sexuality

Content: lessons focused on developing self-esteem

personal decision-making, gaining insights into a

person's identity and sexual development, the role

of the social environment (e.g., peers, family, close

Activities: low-tech, computer-based interactive

sex education. Participants also develop IT and

creative skills, which improve their job prospects.

Dose/frequency/duration: 14 lessons over a period

Theory used: Theory of Planned Behaviour and

Health Belief Model.

Objectives: to reduce the incidence of HIV, STI and unwanted pregnancy by providing knowledge

and skills to enable youth reduce sexual risk, delay

sexual debut and appropriate use of health services

No intervention
The comparison received nothing while waiting

to receive intervention
(waiting-list control group). for sexual health issues.
12 months, 36 months and

96 months (8 years)

Immediate

10 months

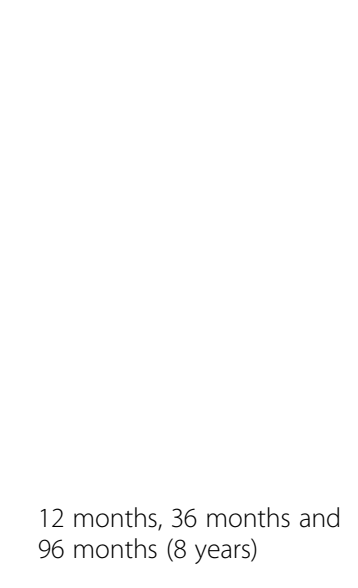


Table 1 Characteristics of Included Studies (Continued)

Content: topics covered included what is reproductive

health and why is it important?; leaving childhood:

Puberty; what are HIV and AIDS?; the facts about

AIDS; the facts about sexually transmitted diseases;

girls and boys have equal abilities; misconceptions

about sex; refusing temptations; saying 'No' to sex;

sexually transmitted diseases: Going to the clinic; how

HIV infection causes AIDS; how Sexually Transmitted

Diseases are spread; the relationship between HIV

and sexually transmitted diseases; the reproductive

organs and their functions; pregnancy and menstruation;

respecting other people's decisions; recognising and

avoiding temptations; protecting yourselves: What are

condoms?; how to avoid HIV infection and AIDS;

Sexually Transmitted Diseases and their consequences;

making good decisions; practising saying 'No'; being

faithful; achieving your future expectations; planning

for your future; and protecting yourself: Correct use of

condoms \& the truth

about condoms.

Activities: (1) In-school interactive teacher led

and peer led programme for primary school

years 5-7. (2) Provision of youth friendly health

services. (3) Distribution and promotion of condom

use in the community. (4) Community mobilization

activities including initial mobilization week and

health weeks annually. Multiple activities were

utilised across the four components of the

intervention including question and answer, guided

discussions, story reading, flip chart illustrations,

role-plays and a scripted drama serial performed

by class peer educators. it also includes: games;

poems; comedy; video films; peer counselling; adult

involvement; printed materials (pamphlets, brochures,

manuals); awareness workshops for district counci

officials, religious leaders and ward development

committee; condom distribution; and Youth Health

Weeks held once a year, where interschool

competitions take place

Dose/frequency/duration: 12, 40-min sessions

per year over 3 years.

Theory used: Social Learning Theory.

Stanton 1998 Secondary schools, Randomised Mean age: 17 Namibia

Controlled Trial
Number: 515
Objectives: to improve basic knowledge on

reproductive biology, HIV/AIDs, and risky

behaviours.

Content: the curriculum focused on improving

knowledge of reproductive biology, risky

behaviours (alcohol, substance abuse, and partner

violence), HIV/AIDs, communication skills and

framework for decision-making.
Delay-control condition i.e., received interventio after the six month of follow up.
Immediate, 6 months and 12 months 
Table 1 Characteristics of Included Studies (Continued)

Activities: variety of narratives, facts, games and

exercises coupled with questions and discussions

embedded in each session

Dose/frequency/duration: two-hour length per

session (14 sessions) over 7 weeks.

Theory used: Protective Motivational Theory.

Taylor 2014 High schools, Randomised Mean age: 14.25 Objectives: to provide information that will improve South Africa Controlled Trial (intervention group) group)

Number: 821

attitudes and encourage intention to prevent

teenage pregnancy.

Content: topics include knowing yourself, the

choice is yours, relationships, making choices,

body development, contraception, peer pressure,

culture, parenthood, responsibility, and human

rights and gender norms.

Activities: role-play, debates, small and large

group discussion, and videos viewing to start

up discussions with students

Dose/frequency/duration: 12 weekly.

Theory used: I-change model.

Tibbits 2011 High schools,_ Randomised Mean age: 14.0 South Africa Controlled Trial Number: 4040

(second cohorts)

2383 (first cohorts)

Objectives: to increase knowledge, promote social,

emotional and refusal skills on substance use and sexual behaviours as well as encouraging

the use of healthy free time.

Content: topics include social-emotional skill

programmes such as decision-making and

self-awareness and positive use of time like

beating boredom, and leisure motivations.

Specific lessons on attitudes, knowledge, skills

surrounding sexual risk and substance use were

also included.

Activities: teachers delivered class lessons.

Dose/frequency/duration: 12 lessons and 6 booster

lessons (each lesson 2-3 class periods).

Theory used: Self-Determination Theory, Selective

Optimization with Compensation and Social

Cognitive Theory.

Van der Secondary schools, Quasi-experimental Age range: 10-30

Maas 2009 Nigeria
Number: 250
Objectives: to increase HIV/AIDS awareness and HIV life skills.

Content: teaching included relevant topics on HIV and life skills.

Activities: sketches, songs, rallies, competitions and videos with scenarios from Africa translated into the local language. UNPFA/UNAIDS peer education toolkit and Family Health International peer-to-peer training guide manuals were used.

Dose/frequency/duration: NR

Theory Used: NR
School life skills programmes. 4 months and 8 months

Students in the comparison schools received the

12 months, 18 months and government mandated

Life Orientation curriculum

which differ substantially

between schools and overlap

minimally with HealthWise

content.

The control group did not receive any peer education. 
Table 1 Characteristics of Included Studies (Continued)

\begin{tabular}{|c|c|c|c|c|c|c|}
\hline Ybarra 2013 & $\begin{array}{l}\text { Secondary schools, } \\
\text { Uganda }\end{array}$ & $\begin{array}{l}\text { Randomised } \\
\text { Controlled Trial }\end{array}$ & $\begin{array}{l}\text { Age range: } 13-19 \\
\text { Number: } 366\end{array}$ & $\begin{array}{l}\text { Objectives: to provide information about HIV, } \\
\text { decision making and communication, motivations } \\
\text { to be healthy, proper use of condom and healthy } \\
\text { relationships. } \\
\text { Content: modules were on information about } \\
\text { HIV including prevention; decision-making and } \\
\text { communication; motivations to be healthy; how } \\
\text { to use a condom to be healthy; and healthy } \\
\text { relationships. } \\
\text { Activities: self-administered computer interactive } \\
\text { sessions. } \\
\text { Dose/duration/frequency: One hour per module } \\
\text { (six modules) over six weeks. } \\
\text { Theory used: Information-Motivation-Behaviour model. }\end{array}$ & $\begin{array}{l}\text { The control arm was } \\
\text { 'treatment as usual': } \\
\text { Participants in the control } \\
\text { arm received no } \\
\text { programming or } \\
\text { interaction beyond the } \\
\text { HIV programming that } \\
\text { was currently being } \\
\text { offered at their school } \\
\text { as part of their usual } \\
\text { schedule of extracurricular } \\
\text { activities. }\end{array}$ & 3 months and 6 months \\
\hline
\end{tabular}


which contains the quality assessment process). Two of the high risks of bias studies $[43,65]$ were found to be at risk of attrition bias due to loss to follow up of more than $30 \%$ and 'unclear' selection bias. The other high-risk study [66] was assessed to be at risk of selection bias because the baseline characteristics of confounders differed between the two arms of the intervention, which were not adjusted for in the analysis, and 'unclear' attrition bias. See Figs. 2 and 3 for risk of bias graph and risk of bias summary for each study respectively.

\section{Description of interventions}

All included interventions delivered comprehensive sexual health education in classroom settings (see Table 1 for interventions description). Comprehensive SBSHE provides participants with information on transmission of sexual infections, safer sex practices and prevention of STIs and unwanted pregnancies [67], in contrast to abstinence-only interventions. Various intervention delivery methods were employed in one or more combinations some of which include lectures or presentations $(n=6)$, group discussions $(n=14)$, role-plays or dramas $(n=14)$, and distribution of information, education and communication (IEC) materials $(n=6)$. Films shows or audio vignettes $(n=7)$, songs $(n=$ $4)$, counselling $(n=6)$, quiz and essay competitions $(n=7)$ were also used. Condoms were distributed in three interventions $[35,62,66]$. Two were interactive computer-based programmes $[68,69]$ and one only involved provision of a printed material [65].

The dose and duration of the interventions varied widely and ranged from a single $1 \mathrm{~h}$ and $45 \mathrm{~min}$ [70] session to multiple sessions delivered over 36 months [35]. However, in general, the interventions employed one session per week of 30-60 min duration over a period of 6-12 weeks $[64,68,71-76]$. Fourteen theories were said to inform the design of 16 of the interventions with Social Learning Theory $(n=6)$, Social Cognitive Theory $(n=3)$ and Theory of Planned Behaviour $(n=3)$ being most frequently used.

\section{Implementation details}

Seven of the interventions were delivered by both teachers and peer educators $[35,41,51,66,69,73,75]$; similarly, seven by peer educators [62,70,77-81]; and three by teachers only [47, 72, 82]. Health educators, community physicians, volunteer adults or youths, nurses or other health personnel were involved in delivering six of the interventions $[43,58,63,71,74,83]$ and one was delivered by the researchers that developed it [84]. Twenty-one of the 31 interventions reported that the facilitators received some form of training (see Additional file 6: Table S6, which contains implementation details of the included interventions).

Only twelve (of 31) studies reported monitoring of implementation and only seven of these [35, 47, 58, 68, 69, 75, 82] reported on fidelity of implementation. Just two studies $[35,75]$ reported that fidelity had been achieved and explained how fidelity had been assessed. In other cases lack of compatibility with local circumstances undermined fidelity of delivery. For example, in the intervention evaluated by Mathews et al. [47] some teachers did not implement condom demonstrations and other skilledbased activities due to overwhelming large number of students per class. Similarly, in the intervention evaluated by Rijsdijk et al. [69] poor availability of computers meant that the intervention had to be modified to delivery through print materials. Sub-sample analyses in this evaluation showed that schools with 'complete' implementation had most of the significant positive effects compared to those with 'partial' implementation [69]. Complete implementation schools are those where the teachers fully

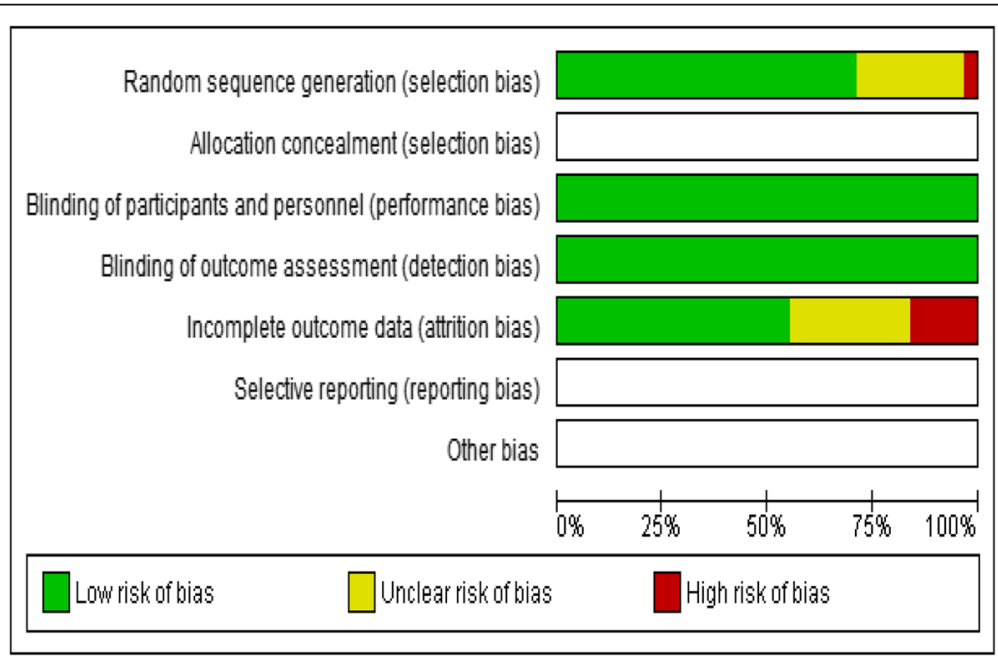

Fig. 2 Risk of bias graph 


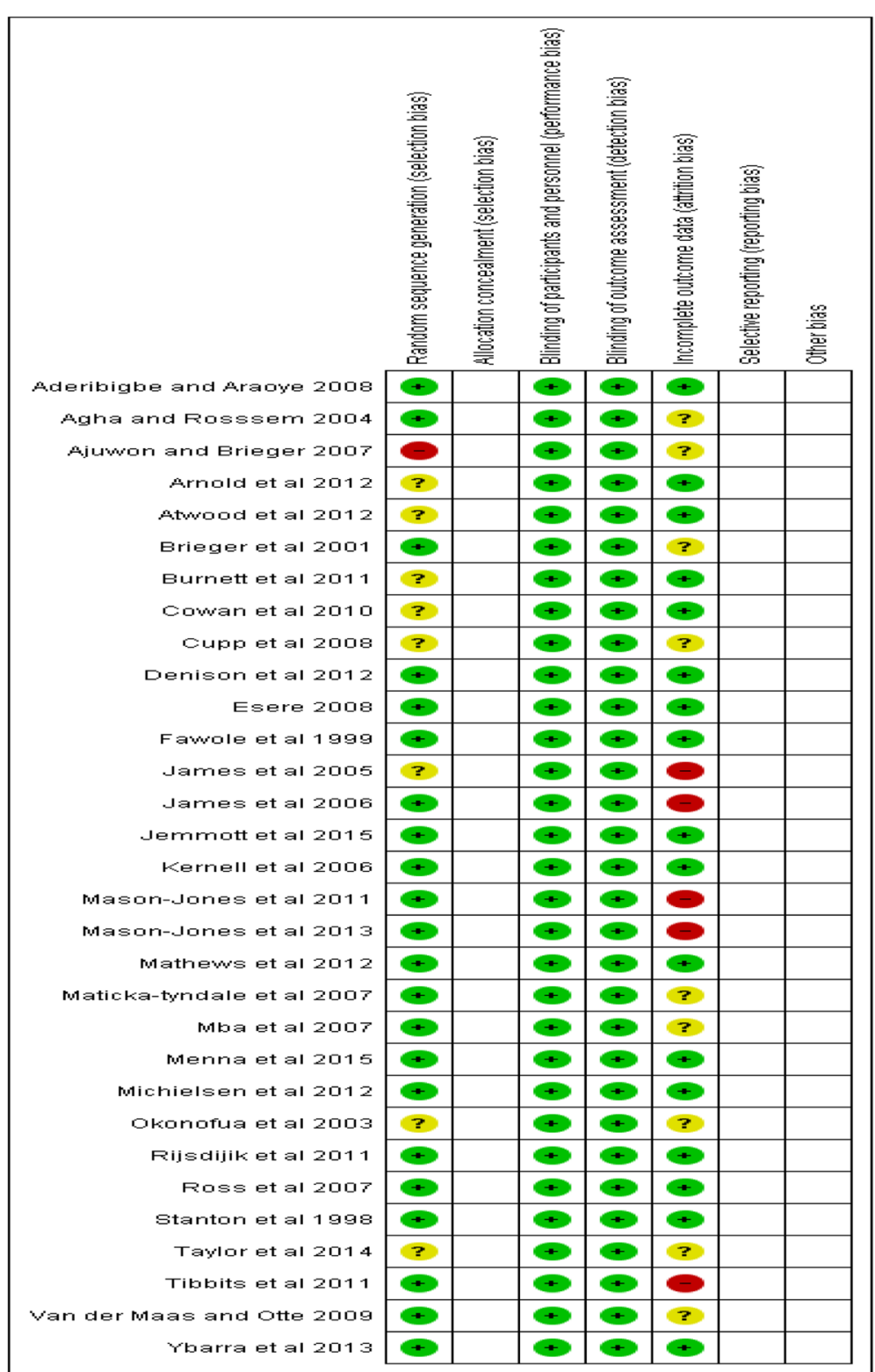

Fig. 3 Risk of bias summary

implemented more than $50 \%$ of the 14 lessons in the programme.

\section{Outcomes}

Three studies reported STI outcomes $[35,55,58]$. Two $[35,58]$, measured HIV infections close to the median follow-up period of 54 months. Cowan et al. [58] found no evidence of an effect on HIV infections among males or females (adjusted odds ratio $(a O R)=1.20,95 \% \mathrm{CI}=$ $0.66-2.18$ and $a O R=1.15,95 \% \mathrm{CI}=0.81-1.64$ respectively). Ross et al. [35] reported incidence rate per 1000 person-years and the intervention also did not significantly reduce HIV infection risk for both short (adjusted rate ratio $(\mathrm{aRR})=0.75, \mathrm{CI}=0.34-1.66$ for young women $)$ and long-term follow-up periods (adjusted prevalence rate $(a P R)=0.91, C I=0.50-1.65$ for men and $a P R=1.07$, $C I=0.68-1.67$ for women).

Three studies [35, 55, 58], also measured HSV2 infections for median follow-up period of 54 months. SBSHE showed no statistically significant effect in reducing the risk of this infection $(O R=1.07,95 \% C I=0.94-1.23, p=0.31$ ) (Fig. 4 Panel a). Ross et al. [35] also did not find any significant effect at long-term follow-up $(a P R=0.94, C I=0.77-1.15$ for males and $a P R=0.96, C I=0.87-1.06$ for females) and similarly, the intervention by Jemmott III et al. [55] did not find a significant effect at 42-month follow-up period. 


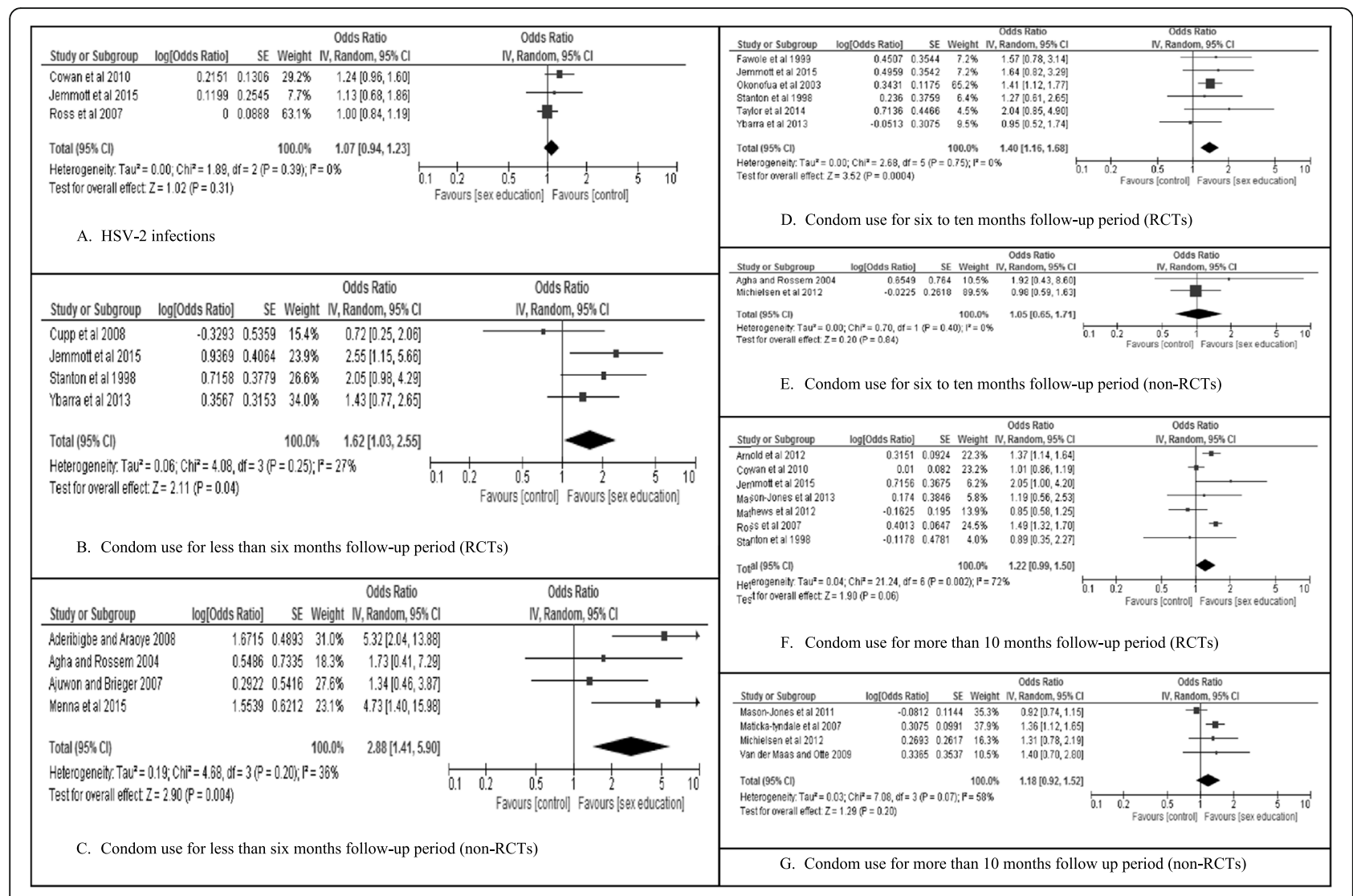

Fig. 4 Forest plots for meta-analysis. a HSV-2 infections. b Condom use for less than six months follow-up period (RCTs). c Condom use for less than six months follow-up period (non-RCTs). $\mathbf{d}$ Condom use for six to ten months follow-up period (RCTs). e Condom use for six to ten months follow-up period (non-RCTs). f Condom use for more than 10 months follow-up period (RCTs). $\mathbf{g}$ Condom use for more than 10 months follow up period (non-RCTs)

Ross et al. [35] measured other STIs including Syphilis, Chlamydia, Gonorrhoea and Trichomonas and found no statistically significant difference between the intervention and control group in the prevalence of these infections for both short and long-term follow-up periods. However, the intervention by Jemmott III et al. [55] significantly reduced curable STIs (Chlamydia, Gonorrhoea and Trichomonas) at 42-month follow-up period $(O R=0.71,95 \% C I=$ $0.54-0.95)$, but not at 54-months follow-up $(O R=1.15$, $95 \% C I=0.84-1.57)$.

All 31 studies assessed self-reported condom use. Fifteen of the interventions [35, 41, 43, 51, 55, 62, 64, $71,72,75,77,79,82,83,85]$ resulted in statisticallysignificant increases in condom use while 16 showed no statistically-significant increases in condom use $[47,58,63,65,66,68-70,73,74,76,78,80,81,84,86]$. No intervention resulted in statistically significant reductions in self-reported condom use.

Twenty of the studies that measured condom use provided adequate data to enable inclusion in meta-analyses $[35,41,47,51,55,58,63,66,68,70,73,74,76,77,79-$ $81,83,85,86]$. Measures of condom use at last sex
$[35,41,47,51,58,63,66,70,73,74,79-81,83,85,86]$, consistent condom use in the last 12 months [77], condom use [76], condom use in the past three months [55] and $100 \%$ condom use in the last three months [68] were in the meta-analysis. All of these measures were coded by the original authors as dichotomous use/non-use scores. For short-term follow-up of less than 6 months, intervention participants were more likely to report condom use in both RCTs $(O R=1.62,95 \% C I=1.03-2.55, p=0.04$ ) (Fig. 4 Panel b) and non-RCTs $(O R=2.88,95 \% C I=1.41-$ 5.90, $p=0.004$ ) (Fig. 4 Panel c). Similarly, intervention participants were more likely to use condoms at intermediate follow-up of 6-10 months with the effect being statistically significant for the RCTs $(O R=1.40,95 \% C I=1.16-1.68, p=$ 0.0004) (Fig. 4 Panel d) but not for non-RCTs $(O R=1.05$, $95 \% C I=0.65-1.71$ ), $p=0.84$ ) (Fig. 4 Panel e). At follow-up of more than 10 months, the effect was marginally significant for RCTs $(O R=1.22,95 \% C I=0.99-1.50, p=0.06)$ (Fig. 4 Panel f) and non-significant for non-RCTs $(O R=1.18$, $95 \% C I=0.92-1.52, p=0.20$ ) (Fig. 4 Panel g).

Sub group analyses showed no effect of type of condom use measure on condom use but greater condom 
use effects when crude, compared to adjusted ORs, were employed (see Additional file 7: Table S7, Panel A-H).

All authors were emailed to acquire missing data. Nonetheless, three studies $[43,71,82]$ were excluded from the meta-analysis because they reported only ORs without $C I$, standard error of mean or $p$-value, precluding further analysis. Another study [78] was also removed because the follow-up period was unclear. Another seven studies $[62,64,65,69,72,75,84]$ measured condom use using continuous measures composed of differing items and could not be included. James et al. [82] measured consistent use of condom in the preceding 6 months by assessing whether a condom was used during all intercourse instances, sometimes or not at all. Mba et al. [84] assessed whether participants practised or intent to practise condom use, as a STI-prevention technique. Esere [64] used a 4-point Likert At-Risk Sexual Behaviour Scale which includes 'do not use condoms while having sex' as a component of the scale. The Ugandan study 'The World Starts with Me' used a 4-item condom use performance behaviour scale to measure condom use [69] and Burnett et al. [72] measured condom use using a 14-item scale. Frequency of condom use was measured on a scale of one (never) to six (always) in the study by Karnell et al. [75]. Finally, Brieger et al. [62] measured contraceptive information including condom use, pills and foaming tablets. This variability of outcome measures prevented the inclusion of these studies in our metaanalysis. Seven of the studies $[43,62,64,71,72,75,82]$ not in the meta-analysis found statistically significant results in increased condom use in the intervention group compared to the control group (see Table 2 which contains results and scales used to measure condom use for studies not included in the meta-analysis).

\section{Quality of evidence and summary of findings}

Table 3 shows the summary of findings and quality of evidence for outcomes included in meta-analyses. The quality of evidence for HSV-2 infection, condom use for 6-10 months and more than 10 months follow-up among RCTs is 'high', which means we are very confident that the true effect lies close to the estimate. We are moderately confident in the evidence for self-reported condom use for less than 6 months follow-up among the RCTs. For the remaining outcome categories, we have limited to very low confidence in the proximity of the estimates to the true effects.

\section{Features of effective interventions}

Small study samples mean that interpretation of the distribution of characteristics across interventions that did or did not result in increased condom use can only be tentative (see Table 4). Nonetheless, we can observe that effective interventions were more often adapted from other programmes, were theory-based, included provision of health services, included activities outside school and were implemented with fidelity.

\section{Discussion}

We conducted a comprehensive review of school-based sexual health education interventions in sub-Saharan Africa evaluated using experimental or quasi-experimental methods. Given the need for public health interventions to reduce sexually transmitted infections, including HIV, and the potential effectiveness of school-based sexual health interventions, the most striking finding is paucity of published evaluations. Across 31 interventions meeting our inclusion criteria, we found no evidence of effectiveness in reducing STIs, including HIV, although one study [55] reported a reduction in curable STIs (Chlamydia, Gonorrhoea and Trichomonas) at one follow-up period. We also found no evidence of harm. This mirrors the findings of previous, comprehensive reviews [22, 25, 87, 88]. More rigorous evaluations of best practice, sustainable, schoolbased sexual health programmes in sub-Saharan Africa are needed.

Interventions were effective in increasing self-reported condom use and, encouragingly, the positive effect on condom use was stronger among evaluations employing more robust experimental methods (RCTs) for intermediate and long-term follow-up periods. Previous reviews $[9,11,26]$ have also found methodically stronger studies to be associated with stronger effects. Perhaps, unsurprisingly, short and intermediate (versus, long followup periods) yielded greater condom use gains, suggesting that further intervention may be needed to sustain behaviour change [11]. These findings contrast with previous suggestions that SBSHE in SSA has a poor record of changing sexual behaviours including condom use [8-10] and supports further investment in SBSHE to promote condom use in low-and middle-income countries $[5,25]$.

Tentative consideration of characteristics found in interventions that did or did not result in statistically-significant increases in condom use recommends that intervention designers should consider adapting interventions from preexisting effective programmes, base their interventions on theory-based logic models of mechanism and link them to health service provision including condom distribution. Finally, intervention designers need to ensure that they assess fidelity and take steps to ensure that interventions are delivered as designed. In this review, just two studies $[35,75]$ reported on fidelity of delivery. It was impossible, therefore, to determine whether or not the interventions were delivered as intended and whether this determined effectiveness. This review highlights the need for further rigorous evaluations of SBSHE to assess impact on incidence or prevalence of STIs including HIV. 
Table 2 Studies That Reported Condom Use Not Included In Meta-Analysis

\begin{tabular}{ll}
\hline Intervention & Scale used to measure condom use \\
\hline At wood et al. 2012 & Use/non-use score \\
Burnett et al. 2011 & 14-item scale \\
Brieger et al. 2001 & $\begin{array}{l}\text { Measured modern contraceptive use including } \\
\text { condom use, pills and foaming tablets. }\end{array}$ \\
Denison et al. 2012 & $\begin{array}{l}\text { Use/non-use score } \\
\text { Esere } 2008\end{array}$ \\
& $\begin{array}{l}\text { A 4-point Likert At-Risk Sexual Behaviour } \\
\text { while having sex' as a component of the scale. }\end{array}$
\end{tabular}

James et al. 2005

$$
\text { Use/non-use score }
$$

James et al. 2006

Karnell et al. 2006

Mba et al. 2007

Rijsdijk et al. 2011

Tibbits et al. 2011
Consistent use of condom in the preceding six months was measured by assessing whether condom was used all the time, sometimes or not at all.

Measured frequency of condom use on a scale of 1 (never) to 6 (always).

Practised or intended to practised STI prevention technique (specifically condom use).

Condom use measured with four-item condom use behaviour (e.g., How often have you obtained a condom in the past 6 months" and "in the past 6 months, did you use a condom when having sex" $a=0.84$ )

Use/non-use score

\section{Finding}

Significant effect of increased consistency of condom use in the last three months at 9-month follow-up period for sexually active participants at baseline and controlling for baseline condom use $\left(B_{9 m t h}=0.032, p<0.05\right)$.

Statistically significant difference in positive direction between the intervention and control group of the study $(F=32.39$, $p<0.001)$.

Found significantly increased reported modern contraceptive use in the intervention group compared to the control (Fisher's exact $p=0.004$ ).

No evidence of difference in reported condom between the intervention and control group at follow up $(a O R=0.93$, $95 \% \mathrm{Cl}=0.57-1.53)$

Significant difference between the intervention and control group $(F=95.93, p<0.05)$.

The intervention (reading Laduma once) was found to have no significant effect on Consistent condom use six weeks post intervention.

Full implementation group used condom more at last sex $(B=-0.80, S E=0.40$, Wald $(1,57)=4.16, p<0.05, O R=0.45)$. However, no effect was found for partial implementation group compared with the full implementation $(B=-0.21$, $S E=0.41$, Wald $(1,157)=0.27, p=0.60, O R=0.81)$

Participants in the intervention group have significantly higher scores than those in the control group $(p<0.05)$.

All sexual active participants in the intervention group practised or intended to practise STI prevention technique at six-week follow up compared to 18 participants at baseline. However, in the control group no change before and after the intervention.

No significant effects of the intervention was found in 'past performance behaviour' including condom use $(F=0.46)$.

Significant effect in the positive direction $(\beta=-0.16$, SE $=0.08$, $p<0.05$ ) for risk at last sex (including condom use with partner at last sex) among virgins at baseline. However, non-significant effect was found for all participants (virgins and non-virgins at baseline). Similarly, non-significant effect was found for condom less sex refusal outcome for all participants including virgins at baseline. Similarly, no difference observed in proportion of participants that reported sexual intercourse in consistent condom use at wave 4 and wave 5 of the study.
In addition, future evaluations need to assess and report on implementation processes including fidelity. This will provide better guidance on how and why interventions 'work' or 'do not work'.

Limitations in the available data recommend caution in interpretation of our findings. For example, condom use reporting is subject to social desirability bias and recall bias, although guidance is available on measures that may minimise such bias [89]. Greater consistency in use of best measures of condom use would assist data synthesis, although sensitivity analysis did not reveal differences in effectiveness as a result of the self-report measures used. Ideally, a larger sample of studies would have been available and further moderators of effectiveness could have been considered. In particular, we would have liked to report on whether interventions in primary or secondary schools were more or less effective and whether studies with greater or lesser risk of bias tended to result in greater increases in condom use. However, for both these sub-group analyses multiple cells included just one study across follow up points. The four evaluations of primary school interventions $[35,41,55,71]$ suggest that these can be just as effective as secondary school interventions and this may indicate that early 
Table 3 Quality of evidence and summary of findings table

\begin{tabular}{|c|c|c|c|c|c|c|c|c|c|c|c|c|}
\hline \multirow[b]{2}{*}{$\begin{array}{l}\text { Outcome (follow } \\
\text { up period) }\end{array}$} & \multicolumn{7}{|c|}{ Quality assessment } & \multicolumn{2}{|c|}{ № of participants } & \multicolumn{2}{|l|}{ Effect } & \multirow[t]{2}{*}{ Quality } \\
\hline & $\begin{array}{l}\text { № of } \\
\text { studies }\end{array}$ & Study design & Risk of bias ${ }^{a}$ & Inconsistency ${ }^{\mathrm{b}}$ & Indirectness $^{c}$ & Imprecision & $\begin{array}{l}\text { Publication or } \\
\text { reporting bias }\end{array}$ & $\begin{array}{l}\text { School-based } \\
\text { sexual health } \\
\text { education }\end{array}$ & $\begin{array}{l}\text { Nothing } \\
\text { or usual } \\
\text { curriculum }\end{array}$ & $\begin{array}{l}\text { Relative } \\
(95 \% \text { Cl) }\end{array}$ & Absolute $(95 \% \mathrm{Cl})$ & \\
\hline $\begin{array}{l}\text { Herpes Simplex } \\
\text { Virus- } 2 \\
\text { (54 months) }\end{array}$ & 3 & randomised trials & not serious & not serious & not serious & not serious ${ }^{d}$ & none & $\begin{array}{l}746 / 6146 \\
(12.1 \%)\end{array}$ & $\begin{array}{l}738 / 6127 \\
(12.0 \%)\end{array}$ & $\begin{array}{l}\text { OR } 1.07 \\
(0.94 \text { to } 1.23)\end{array}$ & $\begin{array}{l}7 \text { more per } 1,000 \\
\text { (from } 6 \text { fewer to } \\
24 \text { more) }\end{array}$ & $\oplus \oplus \oplus \oplus H \| G H$ \\
\hline $\begin{array}{l}{ }^{*} \text { Condom use } \\
\text { (less than } \\
\text { six months) }\end{array}$ & 4 & randomised trials & not serious & not serious & not serious & serious $^{\mathrm{e}}$ & none & $\begin{array}{l}332 / 741 \\
(44.8 \%)\end{array}$ & $\begin{array}{l}295 / 720 \\
(41.0 \%)\end{array}$ & $\begin{array}{l}\text { OR } 1.62 \\
(1.03 \text { to } 2.55)\end{array}$ & $\begin{array}{l}120 \text { more per } 1,000 \\
\text { (from } 7 \text { more to } \\
229 \text { more) }\end{array}$ & $\begin{array}{l}\oplus \oplus \oplus \circ \\
\text { MODERATE }\end{array}$ \\
\hline $\begin{array}{l}{ }^{*} \text { Condom use } \\
\text { (less than } \\
\text { six months) }\end{array}$ & 4 & $\begin{array}{l}\text { quasi-experimental } \\
\text { trials }\end{array}$ & not serious & not serious & not serious & Serious $^{f}$ & None & $\begin{array}{l}90 / 226 \\
(39.8 \%)\end{array}$ & $\begin{array}{l}63 / 197 \\
(32.0 \%)\end{array}$ & $\begin{array}{l}\text { OR } 2.88 \\
(1.41 \text { to } 5.90)\end{array}$ & $\begin{array}{l}255 \text { more per } 1,000 \\
\text { (from } 79 \text { more to } \\
415 \text { more) }\end{array}$ & $\oplus \oplus \circ \circ$ LOW \\
\hline $\begin{array}{l}{ }^{*} \text { Condom use } \\
\text { (six to } 10 \text { months) }\end{array}$ & 6 & randomised trials & not serious & not serious & not serious & not serious ${ }^{9}$ & none & $\begin{array}{l}485 / 1238 \\
(39.2 \%)\end{array}$ & $\begin{array}{l}494 / 1494 \\
(33.1 \%)\end{array}$ & $\begin{array}{l}\text { OR } 1.40 \\
(1.16 \text { to } 1.68)\end{array}$ & $\begin{array}{l}78 \text { more per } 1,000 \\
\text { (from } 34 \text { more to } \\
123 \text { more) }\end{array}$ & $\oplus \oplus \oplus \oplus \mathrm{HIGH}$ \\
\hline $\begin{array}{l}\text { Condom use } \\
\text { (six to } 10 \text { months }\end{array}$ & 2 & $\begin{array}{l}\text { quasi-experimental } \\
\text { trials }\end{array}$ & not serious & not serious & not serious & serious $^{\text {h }}$ & $\begin{array}{l}\text { publication } \\
\text { bias strongly } \\
\text { suspected }^{\prime}\end{array}$ & $\begin{array}{l}62 / 146 \\
(42.5 \%)\end{array}$ & $\begin{array}{l}55 / 131 \\
(42.0 \%)\end{array}$ & $\begin{array}{l}\text { OR } 1.05 \\
(0.65 \text { to } 1.71)\end{array}$ & $\begin{array}{l}12 \text { more per } 1,000 \\
\text { (from } 100 \text { fewer to } \\
133 \text { more) }\end{array}$ & $\begin{array}{l}\text { ФOOO VERY } \\
\text { LOW }\end{array}$ \\
\hline $\begin{array}{l}\text { *Condom use } \\
\text { (more than } \\
10 \text { months) }\end{array}$ & 7 & randomised trials & not serious & not serious & not serious & not serious ${ }^{j}$ & none & $\begin{array}{l}2955 / 8106 \\
(36.5 \%)\end{array}$ & $\begin{array}{l}2678 / 8868 \\
(30.2 \%)\end{array}$ & $\begin{array}{l}\text { OR } 1.22 \\
(0.99 \text { to } 1.50)\end{array}$ & $\begin{array}{l}43 \text { more per } 1,000 \\
\text { (from } 2 \text { fewer to } \\
92 \text { more) }\end{array}$ & $\oplus \oplus \oplus \oplus \mathrm{H} \mid \mathrm{GH}$ \\
\hline $\begin{array}{l}\text { Condom use } \\
\text { (more than } \\
10 \text { months) }\end{array}$ & 4 & $\begin{array}{l}\text { quasi-experimental } \\
\text { trials }\end{array}$ & not serious & not serious & not serious & Serious $^{k}$ & none & $\begin{array}{l}1442 / 2205 \\
(65.4 \%)\end{array}$ & $\begin{array}{l}1647 / 2649 \\
(62.2 \%)\end{array}$ & $\begin{array}{l}\text { OR } 1.18 \\
(0.92 \text { to } 1.52)\end{array}$ & $\begin{array}{l}38 \text { more per } 1,000 \\
\text { (from } 20 \text { fewer to } \\
92 \text { more) }\end{array}$ & $\begin{array}{l}\text { ФOOO VERY } \\
\text { LOW }\end{array}$ \\
\hline
\end{tabular}

Cl Confidence interval, OR Odds ratio, *outcomes with statistically significant positive results

a Quality was assessed as 'not serious' for all outcomes because majority of the studies included were of 'low' to 'moderate' risk of bias

${ }^{b} \mathrm{I}^{2}$ were all below $75 \%$ and therefore, quality was assessed as 'not serious' for all the outcomes

'Quality was assessed as 'not serious' for all outcomes because the interventions were fairly similar, participants were adolescents or young adults and all assessed similar outcomes (condom use and laboratory test of Herpes Simplex Virus-2)

${ }^{\mathrm{d}}$ Relative risk increase or decrease is less than $25 \%(95 \% \mathrm{Cl}$ of $0.97-1.23)$

Relative risk increase or decrease is greater than $25 \%(95 \% \mathrm{Cl}$ of 1.03 to 2.55$)$

Relative risk increase or decrease is greater than $25 \%(95 \% \mathrm{Cl}$ of 1.41 to 5.90$)$

gRelative risk increase or decrease is very close to $25 \%$ confidence interval (95\% Cl of 1.16 to 1.68$)$

${ }^{\text {h}}$ Relative risk increase or decrease is greater than $25 \%(95 \% \mathrm{Cl}$ of 0.65 to 1.75 )

'Funnel plot was asymmetrical

${ }^{k}$ Relative risk increase or decrease is greater than $25 \%(95 \% \mathrm{Cl}$ of 0.92 to 1.52$)$ 
Table 4 Frequencies of occurrence of features associated with effectiveness

\begin{tabular}{|c|c|c|}
\hline Intervention Characteristic & $\begin{array}{l}\text { Interventions } \\
\text { with benefit } \\
(N=15)\end{array}$ & $\begin{array}{l}\text { Interventions } \\
\text { without benefit } \\
(N=16)\end{array}$ \\
\hline $\begin{array}{l}\text { Need assessment of target } \\
\text { participants and involvement } \\
\text { of stakeholders (parents, teachers } \\
\text { or students) in designing the } \\
\text { intervention }\end{array}$ & $9(60 \%)$ & $8(50 \%)$ \\
\hline $\begin{array}{l}\text { Adapting from other programs } \\
\text { or curriculum that are found to } \\
\text { be efficacious. }\end{array}$ & $7(47 \%)$ & $2(13 \%)$ \\
\hline Theory-based & $9(60 \%)$ & $5(29 \%)$ \\
\hline Skilled-based & $10(67 \%)$ & $9(56 \%)$ \\
\hline $\begin{array}{l}\text { Provision of adolescents health } \\
\text { services }\end{array}$ & $3(20 \%)$ & $1(6 \%)$ \\
\hline Distribution of condoms & $2(13 \%)$ & $1(6 \%)$ \\
\hline $\begin{array}{l}\text { Activities outside school } \\
\text { environment }\end{array}$ & $6(40 \%)$ & $2(12 \%)$ \\
\hline Training of facilitators & 10(67\%) & $11(65 \%)$ \\
\hline $\begin{array}{l}\text { Implementation of intervention } \\
\text { with fidelity }\end{array}$ & $2(13 \%)$ & $0(0.00)$ \\
\hline
\end{tabular}

school-based intervention is likely to be more effective. Similarly, we would have liked to assess whether effects were greater or lesser for young men and women but only four studies $[35,41,58,79]$ included in the metaanalysis presented separate gender analyses. It is worth noting too that because blinding is impossible in relation to school-based sexual health education, we were only able to employ two critical, of four dimensions of the Cochrane Collaboration Tool assessed to score the overall risk of bias of the studies in this review. Reviewing studies published in English may have limited our sample. In addition, although double screening of 500 randomly selected title and abstract entries showed near perfect agreement between two reviewers (generating an ACI score of 0.98) further double screening at this stage could have been conducted.

\section{Conclusion}

We conducted a review of school-based sexual health education interventions in sub-Saharan Africa. Interventions to safeguard adolescents from sexually transmitted infections, including HIV are especially needed in subSaharan Africa. School-based interventions have the potential to be inclusive and to provide comprehensive preventive education and training. We assessed the impact of such interventions on incidence or prevalence of STIs and self-reported condom use. We also identified characteristics associated with effective interventions. We found no effect of the interventions on STIs, however, some positive effect on condom use was observed.
Certain features present among interventions effective in promoting condom use were observed. Despite limitations, our review indicates that school-based sexual health education may be an effective strategy to promote condom use among sub-Saharan African adolescents over periods of up to 10 months. Interventions may be optimised by including features found in previous effective programmes. Above all, this review highlights the need for further rigorous evaluations of school-based sexual health education interventions in sub-Saharan Africa including assessment of infection prevalence and fidelity of delivery. Guidance on reporting implementation processes including fidelity would be helpful to intervention designers.

\section{Additional files}

Additional file 1: Review Protocol. (DOCX $71 \mathrm{~kb}$ )

Additional file 2: Search Strategy for Medline Which Was Modified and Used In Other Databases. (DOCX 21 kb)

Additional file 3: Data Extraction Form. (DOCX $26 \mathrm{~kb}$ )

Additional file 4: Lists of Excluded Studies with Reasons for the Exclusion. (DOCX $28 \mathrm{~kb}$ )

Additional file 5: Modified Cochrane Collaboration Tool for Assessing Risk of Bias. (DOCX 45 kb)

Additional file 6: Implementation Details. (DOCX $33 \mathrm{~kb}$ )

Additional file 7: Forest Plots for Sensitivity Analyses. (DOCX 96 kb)

\section{Abbreviations}

AIDS: Acquired immune deficiency syndrome; aOR: Adjusted odds ratio; aPR: Adjusted prevalence rate; aRR: Adjusted rate ratio; Cl: Confidence interval; GRADE: Grading of recommendations assessment, development and evaluation; HIV: Human immunodeficiency virus; HP4RY: HIV prevention intervention for rural youth; HSV2: Herpes simplex virus-2; P $^{2}$ : I-squared statistic; IEC: Information, education and communication; MkV: Mema Kwa Vijana; NR: Not reported; OR: Odds ratio; PSABH: Primary school action for better health; RCT: Randomised controlled trial; SATZ: Promoting sexual and reproductive health, school-based HIV/AIDS intervention in sub-Saharan Africa; SBSHE: School-based Sexual Health Education; SoF: Summary of findings table; sSA: Sub-Saharan Africa; STI: Sexually transmitted infection

\section{Acknowledgements}

We thank Professor Catherine Mathews (Director of the Health Systems Research Unit, in the Cape Town office of the Medical Research Council) for her help in sourcing articles published in African journals.

\section{Funding}

This work presents independent research funded by the UK National Institute for Health Research (NIHR), School for Public Health research and the NIHR Collaboration for Leadership in Applied Health Research and Care of the South West Peninsula (PenCLAHRC). The views expressed in this paper are those of the authors and not necessarily those of NIHR, the University of Exeter or the UK Department of Health.

Availability of data and materials

All data on which the conclusions of the manuscript rely were obtained from the original primary studies cited in the manuscript.

\section{Authors' contributions}

SAS contributed to conception and design of the study; search and selection of studies; data extraction, analysis and interpretation; and drafting of the final manuscript. CA contributed to the conception and design of the study; data collection, interpretation of data; writing and critical revision of the manuscript and supervised the work. SD contributed to the study design 
and conception; selection and data extraction of the included studies; and critical revision of manuscript. SB contributed in data extraction; data analysis and interpretation and critical revision of the final manuscript. Authors order reflects the extent of contribution to the research. All authors have given approval of the final manuscript and agree to take public responsibility of the content of appropriate portions.

\section{Competing interests}

The authors declare that they have no competing interests.

\section{Consent for publication}

Not applicable.

\section{Ethics approval and consent to participate}

Not applicable.

\section{Author details}

${ }^{1}$ Psychology Applied To Health, University of Exeter Medical School, College House, St Lukes Campus, Exeter EX1 2 LU, UK. ${ }^{2}$ NIHR CLAHRC South West Peninsula (PenCLAHRC), University of Exeter Medical School, St Luke's Campus, Exeter EX1 2 LU, UK.

Received: 27 May 2016 Accepted: 23 September 2016

Published online: 10 October 2016

\section{References}

1. World Health Organization. Global incidence and prevalence of selected curable sexually transmitted infections-2008. Geneva: World Health Organization; 2012

2. Gottlieb SL, Low N, Newman LM, Bolan G, Kamb M, Broutet N. Toward global prevention of sexually transmitted infections (STIS): The need for STI vaccines. Vaccine. 2014:32(14):1527-35.

3. UNAIDS. The Gap Report'. Geneva: UNAIDS; 2014.

4. World Health Organization. Mortality, morbidity and disability in Adolescent What we can learn from mortality data? Maternal, newborn, child and adolescent health, Data, statistics and epidemiology. Geneva: WHO; 2015. Available at: http://apps.who.int/adolescent/second-decade/section3/page2/ mortality.html. Accessed 12 Nov 2015.

5. Fonner VA, Armstrong KS, Kennedy CE, O'Reilly KR, Sweat MD. School based sex education and HIV prevention in low-and middle-income countries: A systematic review and meta-analysis. PLoS One. 2014;9(3):e89692.

6. Mavedzenge SN, Luecke E, Ross DA. Effective approaches for programming to reduce adolescent vulnerability to HIV infection, HIV risk, and HIV-related morbidity and mortality: a systematic review of systematic reviews. JAIDS J Acquir Immune Defic Syndr. 2014:66:S154-69.

7. Schaalma HP, Abraham C, Gillmore MR, Kok G. Sex education as health promotion: what does it take? Arch Sex Behav. 2004;33(3):259-69.

8. Gallant M, Maticka-Tyndale E. School-based HIV prevention programmes for African youth. Soc Sci Med. 2004;58(7):1337-51.

9. Kaaya SF, Mukoma W, Flisher AJ, Klepp K-I. School-Based Sexual Health Interventions in Sub-Saharan Africa: A Review. Soc Dyn. 2002:28(1):64-88

10. Paul-Ebhohimhen VA, Poobalan A, Teijlingen ER. A systematic review of school-based sexual health interventions to prevent STI/HIV in sub-Saharan Africa. BMC Public Health. 2008:8:4(1)

11. Amaugo LG, Papadopoulos C, Ochieng BM, Ali N. The Effectiveness of HIV/AIDS School-Based Sexual Health Education Programmes in Nigeria: A Systematic Review. Health Educ Res. 2014;29(4):633-48.

12. Wamoyi J, Mshana G, Mongi A, Neke N, Kapiga S, Changalucha J. A review of interventions addressing structural drivers of adolescents' sexual and reproductive health vulnerability in sub-Saharan Africa: implications for sexual health programming. Reprod Health. 2014;11(1):88.

13. Michielsen $K$, Chersich M, Temmerman M, Dooms T, Rossem R. Nothing as practical as a good theory? The theoretical basis of HIV prevention interventions for young people in sub-Saharan Africa: a systematic review. Special Issue: Psychosocial Correlates Among Adolescents of Responses to HIV Prevention Interventions, Article-345327. 2012.

14. Michielsen K, Chersich MF, Luchters S, De Koker P, Van Rossem R, Temmerman M. Effectiveness of HIV prevention for youth in subSaharan Africa: systematic review and meta-analysis of randomized and nonrandomized trials. Aids. 2010; 24(8):1193-202.
15. Yankah E, Aggleton P. Effects and effectiveness of life skills education for HIV prevention in young people. AIDS Educ Prev. 2008;20(6):465-85.

16. Harrison A, Newell M-L, Imrie J, Hoddinott G. HIV prevention for South African youth: which interventions work? A systematic review of current evidence. BMC Public Health. 2010;10(1):1.

17. Agbemenu K, Schlenk EA. An integrative review of comprehensive sex education for adolescent girls in Kenya. J Nurs Sch. 2011;43(1):54-63.

18. Mavedzenge SMN, Doyle AM, Ross DA. HIV prevention in young people in sub-Saharan Africa: a systematic review. J Adolesc Health. 2011;49(6):568-86.

19. Robin L, Dittus P, Whitaker D, Crosby R, Ethier K, Mezoff J, et al. Behavioral interventions to reduce incidence of HIV, STD, and pregnancy among adolescents: a decade in review. J Adolesc Health Care. 2004;34(1):3-26.

20. Sales J, Milhausen R, DiClemente RJ. A decade in review: building on the experiences of past adolescent STI/HIV interventions to optimise future prevention efforts. Sex Transm Infect. 2006:82(6):431-6.

21. Morrison-Beedy D, Nelson LE. HIV prevention interventions in adolescent girls: what is the state of the science? Worldviews Evid Based Nurs. 2004; 1(3):165-75

22. Kirby DB, Laris B, Rolleri LA. Sex and HIV education programs: their impact on sexual behaviors of young people throughout the world. J Adolesc Health. 2007:40(3):206-17.

23. Speizer IS, Magnani R, Colvin CE. The effectiveness of adolescent reproductive health interventions in developing countries: a review of the evidence. J Adolesc Health. 2003;33(5):324-48.

24. DiCenso A, Guyatt G, Willan A, Griffith L. Interventions to reduce unintended pregnancies among adolescents: systematic review of randomised controlled trials. BMJ. 2002;324(7351):1426.

25. Kirby D, Obasi A, Laris B. The effectiveness of sex education and HIV education interventions in schools in developing countries. Tech Rep Ser-World Health Org. 2006:938:103.

26. Scott-Sheldon LAJ, Walstrom P, Harrison A, Kalichman SC. Sexual risk reduction interventions for HIV prevention among South African youth: a meta-analytic review. Curr HIV Res. 2013;11(7):549-58.

27. Moher D, Liberati A, Tetzlaff J, Altman DG. Preferred reporting items for systematic reviews and meta-analyses: the PRISMA statement. Ann Intern Med. 2009:151(4):264-9.

28. Lewin KM, Sabates R. Who gets what? Is improved access to basic education pro-poor in Sub-Saharan Africa? Int J Educ Dev. 2012;32(4):517-28.

29. Gwet KL. Computing inter-rater reliability and its variance in the presence of high agreement. Br J Math Stat Psychol. 2008:61(1):29-48.

30. Higgins JPT, Green S, editors. Cochrane Handbook for Systematic Reviews of Interventions Version 5.1.0 [updated March 2011], The Cochrane Collaboration. 2011. Available from handbook.cochrane.org.

31. Jadad AR, Moore RA, Carroll D, Jenkinson C, Reynolds DJM, Gavaghan DJ, et al. Assessing the quality of reports of randomized clinical trials: is blinding necessary? Control Clin Trials. 1996;17(1):1-12.

32. Review Manager (RevMan). [Computer program]. Version 5.3. Copenhagen: The Nordic Cochrane Centre TCC; 2014

33. Schünemann $\mathrm{H}$, Brożek J, Guyatt G, Oxman A, editors. GRADE handbook for grading quality of evidence and strength of recommendations. Updated October 2013. The GRADE Working Group. 2013. Available from quidelinedevelopment. org/handbook

34. GRADEpro GDT: GRADEpro Guideline Development Tool [Software]. McMaster University dbEP, Inc.). Available from gradepro.org. Accessed 25 Jul 2016.

35. Ross DA, Changalucha J, Obasi Al, Todd J, Plummer ML, Cleophas-Mazige B, et al. Biological and behavioural impact of an adolescent sexual health intervention in Tanzania: a community-randomized trial. Aids. 2007;21(14):1943-55.

36. Hayes RJ, Changalucha J, Ross DA, Gavyole A, Todd J, Obasi AIN, et al. The MEMA kwa Vijana Project: Design of a community randomised trial of an innovative adolescent sexual health intervention in rural Tanzania. Contemp Clin Trials. 2005:26(4):430-42.

37. Plummer ML, Wight D, Obasi AIN, Wamoyi J, Mshana G, Todd J, et al. A process evaluation of a school-based adolescent sexual health intervention in rural Tanzania: the MEMA kwa Vijana programme. Health Educ Res. 2007;22(4):500-12.

38. Obasi Al, Cleophas B, Ross DA, Chima KL, Mmassy G, Gavyole A, et al. Rationale and design of the MEMA kwa Vijana adolescent sexual and reproductive health intervention in Mwanza Region, Tanzania. Aids CarePsychol Socio-Med Aspects AIDS/HIV. 2006;18(4):311-22.

39. Larke N, Cleophas-Mazige B, Plummer ML, Obasi Al, Rwakatare M, Todd J, et al. Impact of the MEMA kwa Vijana Adolescent Sexual and Reproductive 
Health Interventions on Use of Health Services by Young People in Rural Mwanza, Tanzania: Results of a Cluster Randomized Trial. J Adolesc Health. 2010;47(5):512-22.

40. Doyle AM, Ross DA, Maganja K, Baisley K, Masesa C, Andreasen A, et al. Long-Term Biological and Behavioural Impact of an Adolescent Sexual Health Intervention in Tanzania: Follow-up Survey of the Community-Based MEMA kwa Vijana Trial. Plos Med. 2010;7(6):e1000287.

41. Maticka-Tyndale E, Wildish J, Gichuru M. Quasi-experimental evaluation of a national primary school HIV intervention in Kenya. Eval Program Plann. 2007;30(2):172-86.

42. Maticka-Tyndale E, Wildish J, Gichuru M. Thirty-Month Quasi-Experimental Evaluation Follow-Up of a National Primary School HIV Intervention in Kenya. Sex Educ: Sex, Soc Learn. 2010;10(2):113-30.

43. Tibbits MK, Smith EA, Caldwell LL, Flisher AJ. Impact of HealthWise South Africa on polydrug use and high-risk sexual behavior. Health Educ Res. 2011; 26(4):653-63.

44. Smith EA, Palen L-A, Caldwell LL, Flisher AJ, Graham JW, Mathews C, et al, Substance use and sexual risk prevention in Cape Town, South Africa: an evaluation of the HealthWise program. Prev Sci. 2008;9(4):311-21.

45. Caldwell LL, Younker AS, Wegner L, Patrick ME, Vergnani T, Smith EA, et al. Understanding leisure-related program effects by using process data in the HealthWise South Africa project. J Park Recreation Adm. 2008;26(2):146.

46. Wegner L, Flisher AJ, Caldwell LL, Vergnani T, Smith EA. Healthwise South Africa: cultural adaptation of a school-based risk prevention programme. Health Educ Res. 2008;23(6):1085-96.

47. Mathews C, Aaro LE, Grimsrud A, Flisher AJ, Kaaya S, Onya H, et al. Effects of the SATZ teacher-led school HIV prevention programmes on adolescent sexual behaviour: Cluster randomised controlled trials in three sub-Saharan African sites. Int Health. 2012;4(2):111-22.

48. Mukoma W, Flisher AJ, Ahmed N, Jansen S, Mathews C, Klepp K-I, et al. Process evaluation of a school-based HIV/AIDS intervention in South Africa. Scand J Public Health. 2009:37(2 suppl):37-47.

49. Flisher AJ, Klepp K-I. School-based HIV/AIDS prevention in sub-Saharan Africa. Scand J Public Health . 2009:37(2):4

50. Aarø LE, Flisher AJ, Kaaya S, Onya H, Fuglesang M, Klepp K-I, et al. Promoting sexual and reproductive health in early adolescence in South Africa and Tanzania: Development of a theory-and evidence-based intervention programme. Scand J Public Health. 2006;34(2):150-8.

51. Arnold R, Maticka-Tyndale E, Tenkorang E, Holland D, Gaspard A, Luginaah I. Evaluation of School- and Community-Based HIV Prevention Interventions with Junior Secondary School Students in Edo State, Nigeria. Afr J Reprod Health. 2012;16(2):103-25.

52. Maticka-Tyndale E, Team HR. Bridging theory and practice in HIV prevention for rural youth, Nigeria. Afr J Reprod Health. 2012;16(2):39-53.

53. Dlamini N, Okoro F, Ekhosuehi UO, Esiet A, Lowik A, Metcalfe K. Empowering teachers to change youth practices: Evaluating teacher delivery and responses to the FLHE programme in Edo State, Nigeria. Afr J Reprod Health. 2012;16(2):87-102.

54. Omorodion F, Akpede E, Maticka-Tyndale E, Agbontean-Eghafona K, Onokerhoraye A, Team HR. The use of National Youth Service Corp members to build AIDS competent communities in rural Edo State Nigeria. Afr J Reprod Health. 2012;16(2):71-86.

55. Jemmott III JB, Jemmott LS, O'Leary A, Ngwane Z, Lewis DA, Bellamy SL, et al. HIV/STI risk-reduction intervention efficacy with South African adolescents over 54 months. Health Psychol. 2015;34(6):610.

56. Jemmott IJB, Jemmott LS, O'Leary A, Ngwane Z, Icard LD, Bellamy SL, et al. School-based randomized controlled trial of an HIV/STD risk-reduction intervention for South African adolescents. Arch Pediatr Adolesc Med. 2010; 10:923-9.

57. Jemmott LS, Jemmott JB, Ngwane Z, Icard L, O'Leary A, Gueits L, et al. 'Let Us Protect Our Future'a culturally congruent evidenced-based HIV/STD riskreduction intervention for young South African adolescents. Health Educ Res. 2014;29(1):166-81.

58. Cowan FM, Pascoe SJ, Langhaug LF, Mavhu W, Chidiya S, Jaffar S, et al. The Regai Dzive Shiri project: results of a randomized trial of an HIV prevention intervention for youth. AIDS (London, England). 2010;24(16): 2541-52.

59. Cowan FM, Pascoe SJ, Langhaug LF, Dirawo J, Chidiya S, Jaffar S, et al. The Regai Dzive Shiri Project: a cluster randomised controlled trial to determine the effectiveness of a multi-component community-based HIV prevention intervention for rural youth in Zimbabwe-study design and baseline results. Trop Med Int Health. 2008;13(10):1235-44.
60. Cowan FM, Langhaug LF, Mashungupa GP, Nyamurera T, Hargrove J, Jaffar S, et al. School based HIV prevention in Zimbabwe: feasibility and acceptability of evaluation trials using biological outcomes. Aids. 2002;16(12):1673-8.

61. Power $R$, Langhaug L, Nyamurera T, Wilson D, Bassett M, Cowan F. Developing complex interventions for rigorous evaluation-a case study from rural Zimbabwe. Health Educ Res. 2004;19(5):570-5.

62. Brieger WR, Delano GE, Lane CG, Oladepo P, Oyediran KA. West African youth initiative: Outcome of a reproductive health education program. J Adolesc Health. 2001;29(6):436-46.

63. Van der Maas F, Otte WM. Evaluation of HIV/AIDS secondary school peer education in rural Nigeria. Health Educ Res. 2009;24(4):547-57.

64. Esere MO. Effect of Sex Education Programme on at-risk sexual behaviour of school-going adolescents in Ilorin, Nigeria. African Health Sciences. 2008;8(2):120-5.

65. James S, Reddy PS, Ruiter RA, Taylor M, Jinabhai CC, Empelen P, et al. The effects of a systematically developed photo-novella on knowledge, attitudes, communication and behavioural intentions with respect to sexually transmitted infections among secondary school learners in South Africa. Health Promot Int. 2005;20(2):157-65.

66. Ajuwon AJ, Brieger WR. Evaluation of a school-based reproductive health education program in rural South Western, Nigeria. Afr J Reprod Health. 2007:11(2):47-59.

67. Research to prevention, Johns Hopkins Bloomberg School of Public Health. School-Based Sex Education Rigorous Evidence-Usable Results. Johns Hopkins University, Baltimore: Johns Hopkins Bloomberg School of 567 Public Health; 2013. Available at: http://www.jhsph.edu/research/centersand-institutes/research-to-prevention/publications/sex-ed-factsheet.pdf. Accessed 15 Nov 2015.

68. Ybarra ML, Bull SS, Prescott TL, Korchmaros JD, Bangsberg DR, Kiwanuka JP. Adolescent Abstinence and Unprotected Sex in CyberSenga, an InternetBased HIV Prevention Program: Randomized Clinical Trial of Efficacy. PLoS One. 2013;8(8):e70083.

69. Rijsdijk LE, Bos AE, Ruiter RA, Leerlooijer JN, Haas B, Schaalma HP. The World Starts With Me: A multilevel evaluation of a comprehensive sex education programme targeting adolescents in Uganda. BMC Public Health. 2011;1:334.

70. Agha S, Rossem R. Impact of a school-based peer sexual health intervention on normative beliefs, risk perceptions, and sexual behavior of Zambian adolescents. J Adolesc Health. 2004;34(5):441-52.

71. Atwood KA, Kennedy SB, Shamblen S, Tegli J, Garber S, Fahnbulleh PW, et al. Impact of School-Based HIV Prevention Program in Post-Conflict Liberia. AIDS Educ Prev. 2012;24(1):68-77.

72. Burnett SM, Weaver MR, Mody-Pan PN, Reynolds Thomas LA, Mar CM. Evaluation of an Intervention to Increase Human Immunodeficiency Virus Testing Among Youth in Manzini, Swaziland: A Randomized Control Trial. J Adolesc Health. 2011;48(5):507-13.

73. Cupp PK, Zimmerman RS, Bhana A, Feist-Price S, Dekhtyar O, Karnell A, et al. Combining and adapting American school-based alcohol and HIV prevention programmes in South Africa: The HAPS project. Vulnerable Child Youth Stud. 2008:3(2):134-42

74. Fawole I, Asuzu M, Oduntan S, Brieger W. A school-based AIDS education programme for secondary school students in Nigeria: a review of effectiveness. Health Educ Res. 1999;14(5):675-83.

75. Karnell AP, Cupp PK, Zimmerman RS, Feist-Price S, Bennie T. Efficacy of an American alcohol and HIV prevention curriculum adapted for use in South Africa: results of a pilot study in five township schools. AIDS Educ Prev. 2006;18(4):295-310.

76. Taylor M, Jinabhai C, Dlamini S, Sathiparsad R, Eggers MS, De Vries H. Effects of a Teenage Pregnancy Prevention Program in KwaZulu-Natal, South Africa. Health Care Women Int. 2014;35(7-9):845-58.

77. Menna T, Ali A, Worku A. Effects of peer education intervention on HIV/AIDS related sexual behaviors of secondary school students in Addis Ababa, Ethiopia: a quasi-experimental study. Reprod Health. 2015;12(1):1.

78. Denison JA, Tsui S, Bratt J, Torpey K, Weaver MA, Kabaso M. Do peer educators make a difference? An evaluation of a youth-led HIV prevention model in Zambian Schools. Health Educ Res. 2012;2:237-47.

79. Okonofua FE, Coplan P, Collins S, Oronsaye F, Ogunsakin D, Ogonor JT, et al Impact of an intervention to improve treatment-seeking behavior and prevent sexually transmitted diseases among Nigerian youths. Int J Infect Dis. 2003;7(1):61-73.

80. Mason-Jones AJ, Mathews C, Flisher AJ. Can peer education make a difference? Evaluation of a South African adolescent peer education program to promote sexual and reproductive health. AIDS Behav. 2011:8:1605-11. 
81. Michielsen K, Beauclair R, Delva W, Roelens K, Van Rossem R, Temmerman $M$. Effectiveness of a peer-led HIV prevention intervention in secondary schools in Rwanda: results from a non-randomized controlled trial. BMC Public Health. 2012;12(1):729.

82. James S, Reddy P, Ruiter RAC, McCauley A, Borne B. The impact of an HIV and AIDS life skills program on secondary school students in Kwazulu-Natal, South Africa. AIDS Educ Prev. 2006;18(4):281-94.

83. Stanton BF, Li X, Kahihuata J, Fitzgerald AM, Neumbo S, Kanduuombe G, et al. Increased protected sex and abstinence among Namibian youth following a HIV risk-reduction intervention: a randomized, longitudinal study. Aids. 1998;12(18):2473-80.

84. $\mathrm{Mba} \mathrm{Cl}$, Obi SN, Ozumba BC. The impact of health education on reproductive health knowledge among adolescents in a rural Nigerian community. J Obstet Gynaecol. 2007;27(5):513-7.

85. Aderibigbe $\mathrm{S}$, Araoye M. Effect of health education on sexual behaviour of students of public secondary schools in llorin, Nigeria. Eur J Sci Res. 2008; 24(1):33-41.

86. Mason-Jones AJ, Flisher AJ, Mathews C. Peer education training for sexual health and well-being in public high schools in South Africa: Is it enough to change peer educators themselves? J Child Adolesc Ment Health. 2013;1: $35-42$.

87 Underhill K, Montgomery P, Operario D. Sexual abstinence only programmes to prevent HIV infection in high income countries: systematic review. BMJ. 2007;335(7613):248

88 Underhill K, Operario D, Montgomery P. Systematic review of abstinence-plus HIV prevention programs in high-income countries. PLoS Med. 2007;4(9):e275.

89 Sheeran P, Abraham C. Measurement of condom use in 72 studies of HIVpreventive behaviour: a critical review. Patient Educ Couns. 1994;24(3):199-216.

\section{Submit your next manuscript to BioMed Central and we will help you at every step:}

- We accept pre-submission inquiries

- Our selector tool helps you to find the most relevant journal

- We provide round the clock customer support

- Convenient online submission

- Thorough peer review

- Inclusion in PubMed and all major indexing services

- Maximum visibility for your research

Submit your manuscript at www.biomedcentral.com/submit 